\title{
Developing an anticancer copper(II) pro-drug based on the nature of cancer cell and human serum albumin carrier IIA subdomain: mouse model of breast cancer
}

\author{
Yi Gou ${ }^{1, *}$, Yao Zhang ${ }^{1, *}$, Jinxu $\mathbf{Q i}^{1}$, Shifang Chen ${ }^{1}$, Zuping Zhou ${ }^{2}$, Xiaoyang $\mathbf{W u}^{3}$, \\ Hong Liang ${ }^{1}$, Feng Yang ${ }^{1,2}$ \\ ${ }^{1}$ State Key Laboratory for The Chemistry and Molecular Engineering of Medicinal Resources, Ministry of Science and Technology \\ of China, Guangxi Normal University, Guilin, Guangxi, China \\ ${ }^{2}$ Guangxi University Key Laboratory of Stem Cell and Pharmaceutical Biotechnology, Guangxi Normal University, Guilin, \\ Guangxi, China \\ ${ }^{3}$ Ben May Department for Cancer Research, University of Chicago, Chicago, IL, USA \\ *These authors have contributed equally to this work \\ Correspondence to: Hong Liang, email: 1437311763@qq.com \\ Feng Yang, email: fyang@mailbox.gxnu.edu.cn
}

Keywords: copper pro-drug, human serum albumin, tumor targeting, therapeutic effect

Received: April 05, 2016

Accepted: July 27, 2016

Published: August 22, 2016

\section{ABSTRACT}

Human serum albumin (HSA)-based drug delivery systems are promising for improving delivery efficiency, anticancer activity and selectivity of anticancer agents. To rationally guide to design HSA carrier for anticancer metal agent, we built a breast mouse model on developing anti-cancer copper $(\mathrm{Cu})$ pro-drug based on the nature of IIA subdomain of HSA carrier and cancer cells. Thus, we first synthesized a new $\mathrm{Cu}$ (II) compound derived from tridentate (E)-N'-(5-bromo-2-hydroxybenzylidene) benzohydrazide Schiff base ligand $(\mathrm{HL})$ containing 2 potential leaving groups [indazole (Ind) and $\left.\mathrm{NO}_{3}{ }^{-}\right]$, namely, $\left[\mathrm{Cu}(\mathrm{L})(\mathrm{Ind}) \mathrm{NO}_{3}\right]$. Structural analysis of the HSA complex showed that $\mathrm{Cu}(\mathrm{L})(\mathrm{Ind})\left(\mathrm{NO}_{3}\right)$ could bind to the hydrophobic pocket of the HSA IIA subdomain. Lys199 and His242 coordinate with $\mathrm{Cu}^{2+}$ by replacing the indazole and $\mathrm{NO}_{3}$ ligands of $\left[\mathrm{Cu}(\mathrm{L})(\mathrm{Ind}) \mathrm{NO}_{3}\right]$. The release behavior of the $\mathrm{Cu}$ compound from the HSA complex is different at different $\mathrm{pH}$ levels. $\left[\mathrm{Cu}(\mathrm{L})(\mathrm{Ind}) \mathrm{NO}_{3}\right]$ can enhance cytotoxicity by 2 times together with HSA specifically in cancer cells but has no such effect on normal cells in vitro. Importantly, our in vivo results showed that the HSA complex displayed increased selectivity and capacity to inhibit tumor growth and was less toxic than $\left[\mathrm{Cu}(\mathrm{L})(\mathrm{Ind}) \mathrm{NO}_{3}\right]$ alone.

\section{INTRODUCTION}

After the unexpected discovery of the antiproliferative activity of cisplatin, many studies have highlighted potent metal-based drugs (metallodrugs) for treating cancers $[1,2]$. Most anticancer metallodrugs have been studied both in vitro and in vivo, and some of these drugs have been tested in clinical trials [3-5]. Even though progress has been made to understand the chemistry of metallodrugs, these emerging therapeutics are associated with concerns such as a lack of water solubility and chemical deficiencies [3, 6-8]. To overcome these concerns, novel drug delivery vehicles must be developed [9-13].
Over the past several decades, various drug delivery systems, including pro-drugs, protein biomolecules, and nanoparticles, which maximize the efficacy of novel metallodrugs, have been developed [14-18]. Human serum albumin (HSA)-based delivery systems provide an interesting approach because HSA is a nontoxic, biocompatible and biodegradable endogenous protein that does not provoke an immune response and does not stimulate the production of antibodies [19]. HSA is the most abundant protein in blood plasma and contains a variety of special active residues, including cysteine and lysine [20]. The efficiency and selectivity of anticancer agents can be improved by chemically coupling these agents with the special residues of albumin [21-27]. 
However, this method often introduces exogenous chemicals in or changes the conformation of albumin [2528]. HSA has 3 major binding sites for binding various exogenous compounds [29-32]. Thus, to overcome this, drugs can be complexed with HSA. Recent studies have shown that the specificity and efficacy of anticancer drugs can be enhanced by complexing them with HSA [33-37]. Interestingly, based on the nature of HSA IIA subdomain, Yang et al. proposed and built a model in vitro on developing copper anticancer drugs by pro-drug strategy [37].

Metallodrugs offer biological and chemical diversity that is distinct from that offered by organic drugs [38]. Biological activity, particularly antitumor activity, of various metals that form a complex with organic ligands is higher than that of just the organic molecules alone [3941]. $\mathrm{Cu}$-containing drugs may serve as promising nextgeneration anticancer agents because $\mathrm{Cu}$ is bioactive and serves as an essential element for human physiological functions [42, 43]. Breast cancer is the most prevalent cancer in women, and it is the leading cause of cancer deaths among women worldwide [44]. Although Yang et al. showed that a $\mathrm{Cu}$ pro-drug designed based on the nature of HSA IIA subdomain had enhanced selectivity and anticancer efficiency to some extent in vitro, its anticancer behavior in vivo was unclear [37]. Therefore, we used the pro-drug strategy to develop an HSA carrier for delivering the $\mathrm{Cu}$ compound in vivo for treatment of breast cancer by performing the following studies: (1) synthesizing a new aroylhydrazone Schiff base-derived $\mathrm{Cu}$ (II) compound containing the 2 leaving groups (Figure 1A), (2) confirming the feasibility of developing an anticancer $\mathrm{Cu}$ pro-drug exploiting the function of cancer cells and by using the HSA IIA subdomain, (3) determining whether the HSA carrier increased the selectivity and therapeutic efficacy of $\left[\mathrm{Cu}(\mathrm{L})(\right.$ Ind $\left.) \mathrm{NO}_{3}\right]$ relative to that of $[\mathrm{Cu}(\mathrm{L})$ (Ind) $\mathrm{NO}_{3}$ ] alone in vivo, (4) determining whether the HSA complex was associated with less side effects than $[\mathrm{Cu}(\mathrm{L})$ (Ind) $\mathrm{NO}_{3}$ ] alone in vivo, and (5) determining the potent anticancer mechanism of $\left[\mathrm{Cu}(\mathrm{L})(\mathrm{Ind}) \mathrm{NO}_{3}\right] / \mathrm{HSA}$ complex.

\section{RESULTS}

\section{Development and structure of the $\mathrm{Cu}$-containing pro-drug}

We developed a $\mathrm{Cu}$-containing pro-drug with improved in vivo selectivity and drug delivery and anticancer efficiency using the structure of cancer cells as well as by using the HSA IIA subdomain. First, we used a tridentate $(E)-N$ '-(5-bromo-2-hydroxybenzylidene) benzohydrazide Schiff base ligand (HL) for developing the $\mathrm{Cu}$ compound (pharmacophore) because the hydrazone class ligands are promising anticancer agent [45-47] and because its hydrophobic $(\log P=3.8)$ and rigid structure may facilitate the binding of the $\mathrm{Cu}$ compound to the HSA IIA subdomain [37]. We selected $\mathrm{NO}_{3}^{-}$and indazole as the second and third ligands (potential leaving groups), respectively (Figure $1 \mathrm{~A}) .\left[\mathrm{Cu}(\mathrm{L})(\mathrm{Ind}) \mathrm{NO}_{3}\right]$ crystallizes in a triclinic system with a space group $P-1$. The asymmetric units contained 1 tridentate Schiff base ligand, $1 \mathrm{Cu}(\mathrm{II})$ center, 1 indazole ligand, and $1 \mathrm{NO}_{3}^{-}$(Figure 1B).

The $\mathrm{Cu}$ (II) metal center, which was formed by combining a nitrogen atom and two oxygen atoms from the Schiff base ligand, a nitrogen atom from the indazole ligand, and one terminal $\mathrm{NO}_{3}^{-}$. The coordination of a polyhedron around the $\mathrm{Cul}$ center formed a distorted square pyramid $(\tau=0.12)$ [48], with the metal displaced from the $\mathrm{O} 1 / \mathrm{N} 2 / \mathrm{O} 2 / \mathrm{N} 3$ basal plane (maximum displacement of $0.09 \AA$ for oxygen atom), and with $\mathrm{NO}_{3}{ }^{-}$at the apex (metal displacement by 0.142 $\AA$ toward $\mathrm{NO}_{3}^{-}$from the mean basal plane). $\mathrm{Cu}-\mathrm{N}$ and $\mathrm{Cu}-\mathrm{O}$ bond distances were in the range of $1.879-2.474$ $\AA$, which were similar to those reported previously [37, 49-51]. Considerable strain existed in the coordination plane around the $\mathrm{Cu}$ (II) center because of the short bite $\left(173.8^{\circ}\right)$ of the $\mathrm{O} 1-\mathrm{N} 2-\mathrm{O} 2$ portion of the Schiff base ligand. The $\mathrm{C} 7-\mathrm{O} 2$ bond distance in the complex was shorter than that in the free ligands [52], which supported the formation of alkoxide after complexation. Dimers were formed in a solid state through $\mathrm{N}-\mathrm{H} \cdots \mathrm{O}$
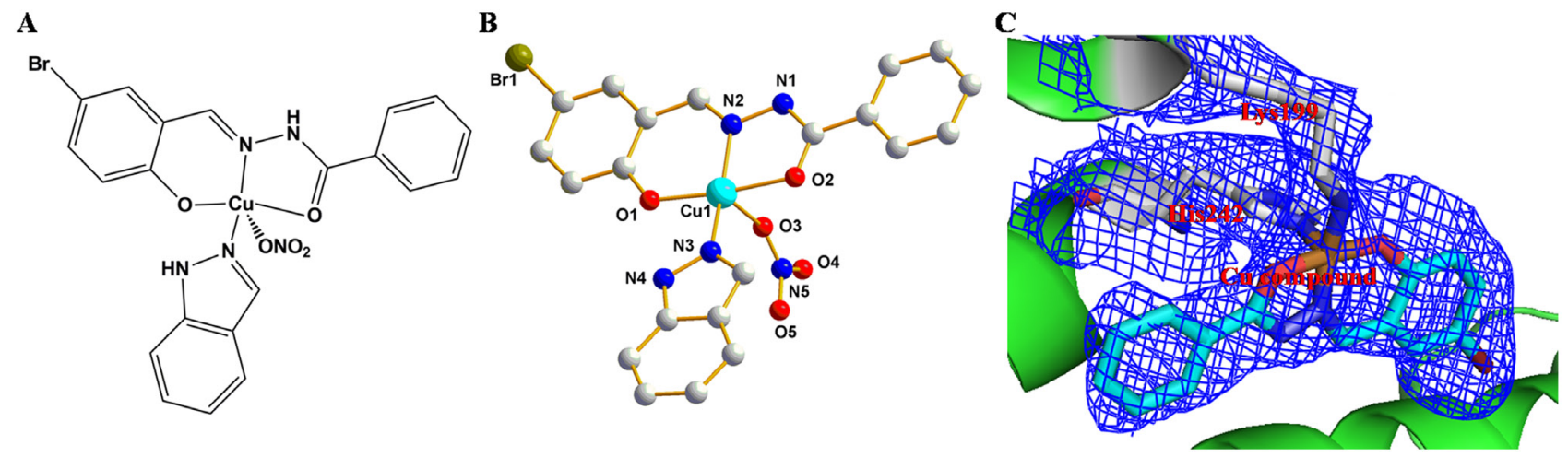

Figure 1: A. and B. Chemical structure of $\left[\mathrm{Cu}(\mathrm{L})(\mathrm{Ind}) \mathrm{NO}_{3}\right]$. C. The experimental $\sigma$ A weighted $2 F_{\mathrm{o}}-F_{\mathrm{c}}$ electron density map (blue, $1 \sigma$ ) of $\mathrm{Cu}$ pro-drug in HSA. 
reactions, which involved a nitrogen atom (N1) from the Schiff base ligand and $\mathrm{NO}_{3}{ }^{-}\left(\mathrm{O}^{\mathrm{i}}\right)$ bonded to $\mathrm{Cu} 1^{\mathrm{i}}$ from an adjacent molecule $\left(\mathrm{N} 1 \cdots \mathrm{O} 3^{\mathrm{i}}=2.902 \AA ; \mathrm{N} 1-\right.$ $\mathrm{H} 1 \cdots \mathrm{O} 3^{\mathrm{i}}$ angle is $152.6^{\circ}$; symmetry code: (i) $1-x,-y$, $2-z$; Supplementary Figure S1). A small proportion of $\pi \cdots \pi$ stacking (Supplementary Figure S1) was observed between pyridine rings in $\left[\mathrm{Cu}(\mathrm{L})(\mathrm{Ind}) \mathrm{NO}_{3}\right]$, which provided some stability to the dimeric structure.

\section{Feasibility of developing the HSA-based $\mathrm{Cu}$ pro-drug}

The fluorescence of HSA at approximately $348 \mathrm{~nm}$ was gradually quenched by intensifying the concentration of $\left[\mathrm{Cu}(\mathrm{L})(\right.$ Ind $\left.) \mathrm{NO}_{3}\right]$ (Supporting Information, Supplementary Figure S2A), suggesting that the $\mathrm{Cu}$ compound is bound closely to the IIA subdomain of HSA [53]. UV-Vis measurements suggested that the $\mathrm{Cu}$ compound can interact with HSA (Supplementary Figure S2B) [54]. Consistently, the MALDI-TOF-mass spectra indicates growth of about $400 \mathrm{Da}$ for the HSA complex as compared to HSA alone, which was equivalent to the molecular weight of approximately one $\mathrm{Cu}$ compound $[\mathrm{Cu}(\mathrm{L})]$ (Supplementary Figure S2C).

To confirm whether the $\mathrm{Cu}$ prodrug could be developed using the HSA IIA subdomain, we determined the structure of the $\mathrm{HSA}-\mathrm{PA}-\left[\mathrm{Cu}(\mathrm{L})(\mathrm{Ind}) \mathrm{NO}_{3}\right]$ complex. The electron density map of the $\mathrm{Cu}$ compound in the HSA complex clearly showed one $\mathrm{Cu}$ compound molecule in the IIA subdomain (Figures $1 \mathrm{C}$ and Supplementary Figure $\mathrm{S} 3)$. Overall, the $\mathrm{HSA}-\mathrm{PA}-\left[\mathrm{Cu}(\mathrm{L})(\mathrm{Ind}) \mathrm{NO}_{3}\right]$ complex was heart shaped (Figure 2A), which was comparable to the previously discovered structures of HSA-FA complexes [55], save for a slight structural change in the amount of adjacent chains at the drug-binding site. In the HSA IIA subdomain, the $\mathrm{Cu}$ compound was bound to a big hydrophobic pocket containing residues Arg218, Arg222, Lys199, Trp214, Leu219, Phe223, Leu234, Leu238, His242, Arg257, Leu260, Ile264, Ser287, Ile290, and
Ala291 (Figure 2B and 2C). Of these residues, Lys 199 and $\mathrm{His} 242$ coordinated with $\mathrm{Cu}^{2+}$ of $\left[\mathrm{Cu}(\mathrm{L})(\mathrm{Ind}) \mathrm{NO}_{3}\right]$ by replacing indazole and $\mathrm{NO}_{3}{ }^{-}$, respectively (Figure $2 \mathrm{~B}$ ). Furthermore, the hydrophobic group of the $\mathrm{Cu}$ compound showed reactions with the side chains of surrounding residues. The nearest distances between the hydrophobic group and the adjacent side chains of HSA ranged from approximately 3.0 to $5.0 \AA$.

\section{In vitro anticancer activity of the HSA complex}

The cytotoxicity of $\left[\mathrm{Cu}(\mathrm{L})\left(\right.\right.$ Ind) $\left.\mathrm{NO}_{3}\right]$ against MCF-7 cells $(1.53 \pm 0.14 \mu \mathrm{M})$ was higher than that of cisplatin $(18.34 \pm 1.67 \mu \mathrm{M})$. The HSA complex showed approximately 2-fold higher toxicity against MCF-7 cells than $\left[\mathrm{Cu}(\mathrm{L})(\mathrm{Ind}) \mathrm{NO}_{3}\right]$ alone but exerted less toxic effects on WI-38 normal lung fibroblast cells (Table 1 and Supplementary Table S3). In addition, the $[\mathrm{Cu}(\mathrm{L})(\mathrm{Ind})$ $\mathrm{NO}_{3}$ ] compound and HSA complex exhibit no multidrugresistant behaviors as exhibited by their skill in eliminating all doxorubicin-sensitive and -resistant MCF-7 and MCF7/ADR cells (Table 1) with no apparent pattern.

\section{In vivo studies of the HSA pro-drug}

To evaluate whether the HSA complex showed enhanced therapeutic efficacy in vivo, we conducted the studies on the xenograft MCF-7 murine breast cancer model.

\section{Acute toxicity of the HSA complex and $[\mathrm{Cu}(\mathrm{L})$ (Ind) $\left.\mathrm{NO}_{3}\right]$}

Acute toxicities of the HSA complex and $[\mathrm{Cu}(\mathrm{L})$ (Ind) $\mathrm{NO}_{3}$ ] were assessed using normal mice. Serum parameters determined at 3 days after the intravenous administration of the HSA complex and $\mathrm{Cu}(\mathrm{L})(\mathrm{Ind}) \mathrm{NO}_{3}$ are listed in Table 2. $\left[\mathrm{Cu}(\mathrm{L})\left(\right.\right.$ Ind) $\left.\mathrm{NO}_{3}\right]$ induced significant nephrotoxicity, with its BUN value $(20.3 \pm 2.4 \mathrm{mmol} / \mathrm{L})$
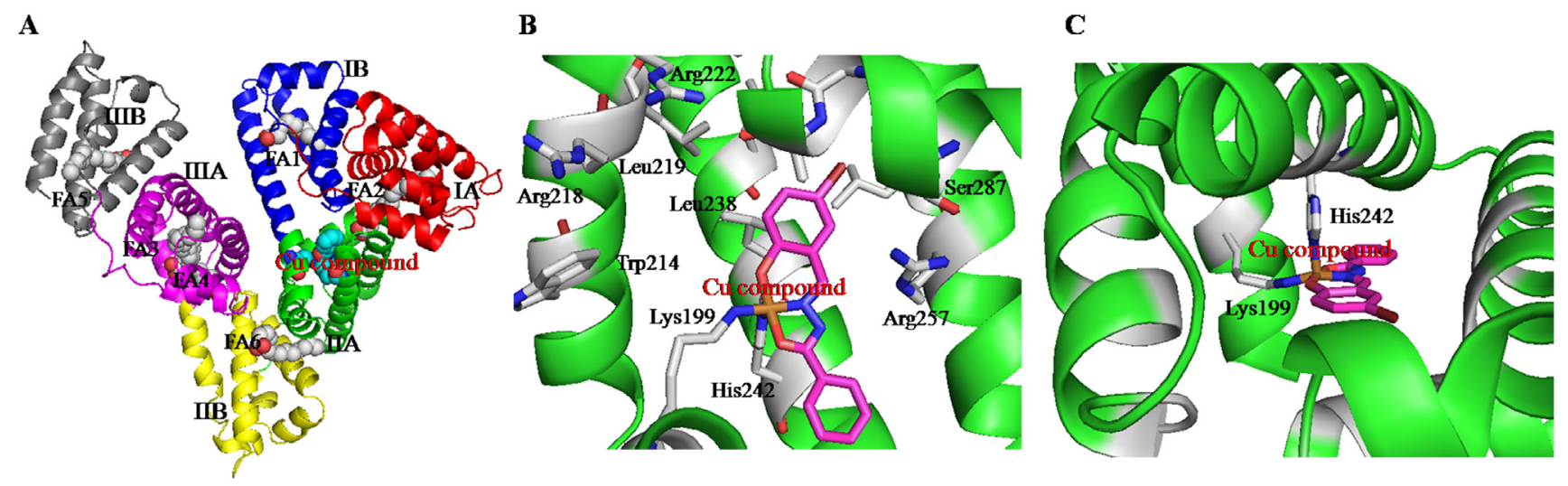

Figure 2: A. The overall structure of HSA complex. B and C. The structural binding environment of Cu prodrug in HSA from different angles. 
Table 1: $\mathrm{IC}_{50}{ }^{a}(\mu \mathrm{M})$ values of $(E)-N^{\prime}$-(5-bromo-2-hydroxybenzylidene)benzohydrazide Schiff base ligand (HL), $\mathrm{Cu}(\mathrm{II})$ compound and HSA complex toward a panel of human cell lines for $48 \mathrm{~h}$

\begin{tabular}{lccc}
\hline \multirow{2}{*}{ Compound } & \multicolumn{3}{c}{ Antitumor activity $\mathbf{I C}_{\mathbf{5 0}}(\boldsymbol{\mu M})$} \\
\cline { 2 - 4 } & $\mathbf{M C F - 7}$ & MCF-7/ADR & WI-38 \\
\hline $\mathrm{HL}$ & $86.2 \pm 6.5$ & $89.5 \pm 6.2$ & $>100$ \\
{$\left[\mathrm{Cu}(\mathrm{L})(\mathrm{Ind}) \mathrm{NO}_{3}\right]$} & $1.53 \pm 0.14$ & $1.78 \pm 0.16$ & $2.58 \pm 0.23$ \\
$\mathrm{HSA}-[\mathrm{Cu}(\mathrm{L})]$ & $0.69 \pm 0.08$ & $0.92 \pm 0.11$ & $2.61 \pm 0.24$ \\
Cisplatin & $18.34 \pm 1.67$ & $20.34 \pm 1.82$ & $18.21 \pm 1.35$ \\
Doxorubicin & $3.54 \pm 0.29$ & $>100$ & - \\
\hline
\end{tabular}

${ }^{\mathrm{a}} \mathrm{IC}_{50}$ values are presented as the mean $\pm \mathrm{SD}$ from three separated experiments.

Table 2: Serological analysis (creatinine kinase CK, blood urea nitrogen BUN, alanine aminotransferase ALT and aspartate aminotransferase $\mathrm{AST})$ of mice injected $\mathrm{NaCl}, \mathrm{Cu}(\mathrm{L})(\mathrm{Ind}) \mathrm{NO}_{3}$ and $\mathrm{HSA}-\mathrm{Cu}(\mathrm{L})$

\begin{tabular}{lcccc}
\hline Complex & CK (U/L) & BUN (mmol/L) & ALT (U/L) & AST (U/L) \\
\hline $\mathrm{NaCl}$ & $341 \pm 13$ & $6.3 \pm 1.1$ & $38.2 \pm 8$ & $89.3 \pm 11$ \\
$\mathrm{Cu}(\mathrm{L})(\mathrm{Ind}) \mathrm{NO}_{3}$ & $382 \pm 32$ & $20.3 \pm 2.4$ & $71.3 \pm 6.4$ & $139 \pm 15$ \\
$\mathrm{HSA}-\mathrm{Cu}(\mathrm{L})$ & $356 \pm 26$ & $9.2 \pm 1.3$ & $54.6 \pm 5.7$ & $109 \pm 8.6$ \\
\hline
\end{tabular}

being higher than that of vehicle control $(\mathrm{NaCl}, 6.3 \pm 1.1$ $\mathrm{mmol} / \mathrm{L})$. While, the BUN $(9.2 \pm 1.3 \mathrm{mmol} / \mathrm{L})$ of HSA complex is similar to $\mathrm{NaCl}$ group, indicating a lower nephrotoxicity caused by HSA complex than $[\mathrm{Cu}(\mathrm{L})$ (Ind) $\mathrm{NO}_{3}$ ]. Serum AST and ALT levels were significantly higher in $\left[\mathrm{Cu}(\mathrm{L})(\mathrm{Ind}) \mathrm{NO}_{3}\right]$-treated mice than in $\mathrm{NaCl}-$ treated mice. In contrast, i.v. administration of the HSA complex induced lesser changes in AST and ALT levels, suggesting that the HSA complex exerted lower hepatotoxicity than free $\left[\mathrm{Cu}(\mathrm{L})(\mathrm{Ind}) \mathrm{NO}_{3}\right]$. However, $\mathrm{CK}$ levels of HSA complex- and $\left[\mathrm{Cu}(\mathrm{L})(\mathrm{Ind}) \mathrm{NO}_{3}\right]$-treated mice were similar to those of control mice, indicating negligible cardiotoxicity.

\section{Antitumor activity of the HSA complex and $\left[\mathrm{Cu}(\mathrm{L})(\right.$ Ind $\left.) \mathrm{NO}_{3}\right]$}

The in vivo antitumor effect of the HSA complex and $\left[\mathrm{Cu}(\mathrm{L})(\mathrm{Ind}) \mathrm{NO}_{3}\right]$ was evaluated using MCF-7 tumorbearing mouse model. Variations in tumor volume and mouse body weight were monitored every 3 days for 24 days (Figure 3 ). At the end of this period, the tumors in nude mice receiving $\mathrm{NaCl}$ grew quickly, attaining an average net volume of $1252 \pm 104 \mathrm{~mm}^{3}$. Compared with $\mathrm{NaCl}$, the HSA complex and $\left[\mathrm{Cu}(\mathrm{L})(\mathrm{Ind}) \mathrm{NO}_{3}\right]$ decreased the net volume of MCF-7 tumor xenografts after 24 days of treatment. Importantly, the HSA complex significantly decreased tumor volume compared with $\mathrm{NaCl}(p<$ 0.001; Figure 3A). The Tumor inhibitory rate (TIR) was computed using differences in tumor weight (Figure 3B).
The TIR of the HSA complex was approximately $64.6 \pm$ $8.7 \%$, which is higher than that of $\left[\mathrm{Cu}(\mathrm{L})(\mathrm{Ind}) \mathrm{NO}_{3}\right]$ alone $(33.2 \pm 5.2 \%)$. Histological examination with hematoxylin and eosin (H\&E) staining and terminal deoxynucleotidyl transferase dUTP nick end labeling (TUNEL) assay were performed to investigate the tumor suppression efficiency of the HSA complex. Tumor cells of mice in the control group were normal and showed no visible apoptosis or necrosis (Figure 4). In contrast, different degrees of tumor cell apoptosis or necrosis were observed in mice treated with the HSA complex and $\left[\mathrm{Cu}(\mathrm{L})(\mathrm{Ind}) \mathrm{NO}_{3}\right]$. Mice treated with the HSA complex showed larger areas of apoptosis and necrosis than those treated with $\left[\mathrm{Cu}(\mathrm{L})(\mathrm{Ind}) \mathrm{NO}_{3}\right]$, indicating that the in vivo antitumor efficacy of the HSA complex was superior to that of $\left[\mathrm{Cu}(\mathrm{L})(\mathrm{Ind}) \mathrm{NO}_{3}\right]$.

\section{Comparison of the side effects of $[\mathrm{Cu}(\mathrm{L})$ (Ind) $\mathrm{NO}_{3}$ l and the HSA complex}

Figure $3 \mathrm{C}$ shows the changes in the body of mice treated with $\mathrm{NaCl},\left[\mathrm{Cu}(\mathrm{L})(\mathrm{Ind}) \mathrm{NO}_{3}\right]$, and HSA complex. Loss of body weight in mice treated with the HSA complex was only approximately $11.4 \pm 0.9 \%$ from the original weight, which was lower than that observed in mice treated with $\left[\mathrm{Cu}(\mathrm{L})(\mathrm{Ind}) \mathrm{NO}_{3}\right]$ (approximately $19.3 \%$ of the original weight), indicating that the HSA complex reduced the side effects induced by free $\left[\mathrm{Cu}(\mathrm{L})(\mathrm{Ind}) \mathrm{NO}_{3}\right]$ (Figure 3C). In addition, drug-related side effects to major organs were observed by pathological section with $\mathrm{H} \& \mathrm{E}$ staining (Figure 5). Serious damage to the liver (hepatic 
$\mathbf{A}$

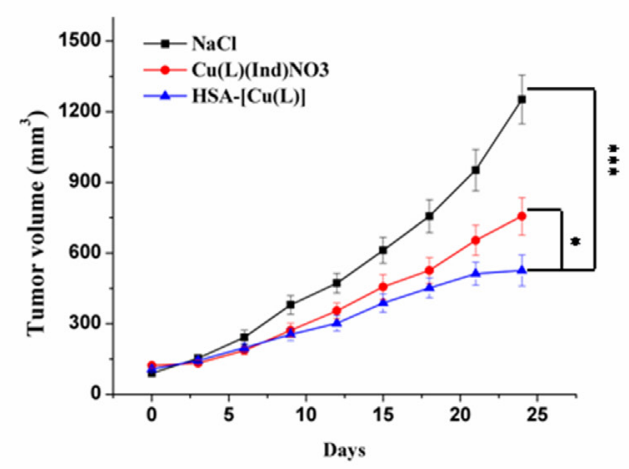

C

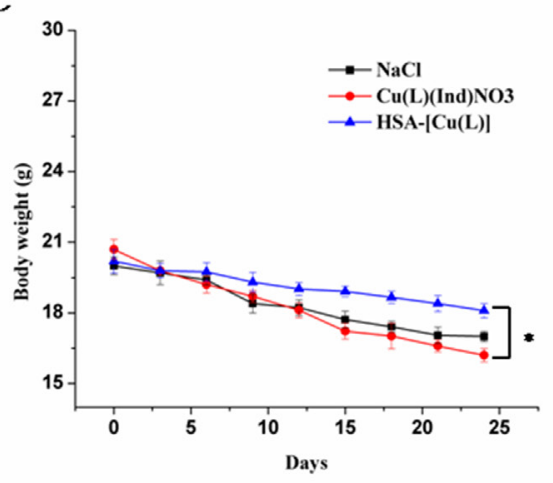

B

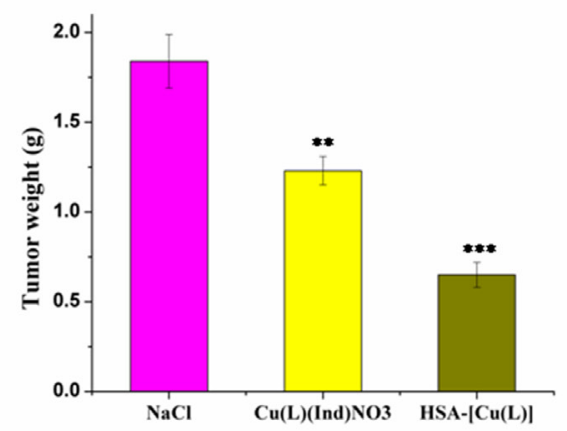

D

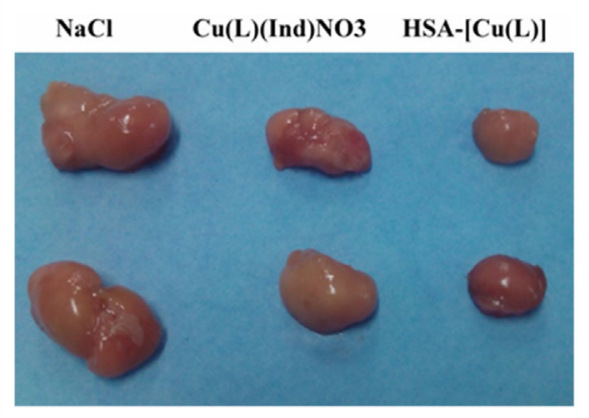

Figure 3: A. Variations of tumor volume after treatment with saline, $\left[\mathrm{Cu}(\mathrm{L})(\mathrm{Ind}) \mathrm{NO}_{3}\right]$ and $\mathrm{HSA}-[\mathrm{Cu}(\mathrm{L})]$. B. Mean weight of tumors separated from mice after different treatments. C. Body weight changes of different formulations. D. Representative tumors separated from animals after intravenous injection of saline, $\left[\mathrm{Cu}(\mathrm{L})(\mathrm{Ind}) \mathrm{NO}_{3}\right]$ and $\mathrm{HSA}-[\mathrm{Cu}(\mathrm{L})]$. Statistical significance: ${ }^{*} p<0.05 ; * * p<0.01 ; * * * p<$ 0.001 .
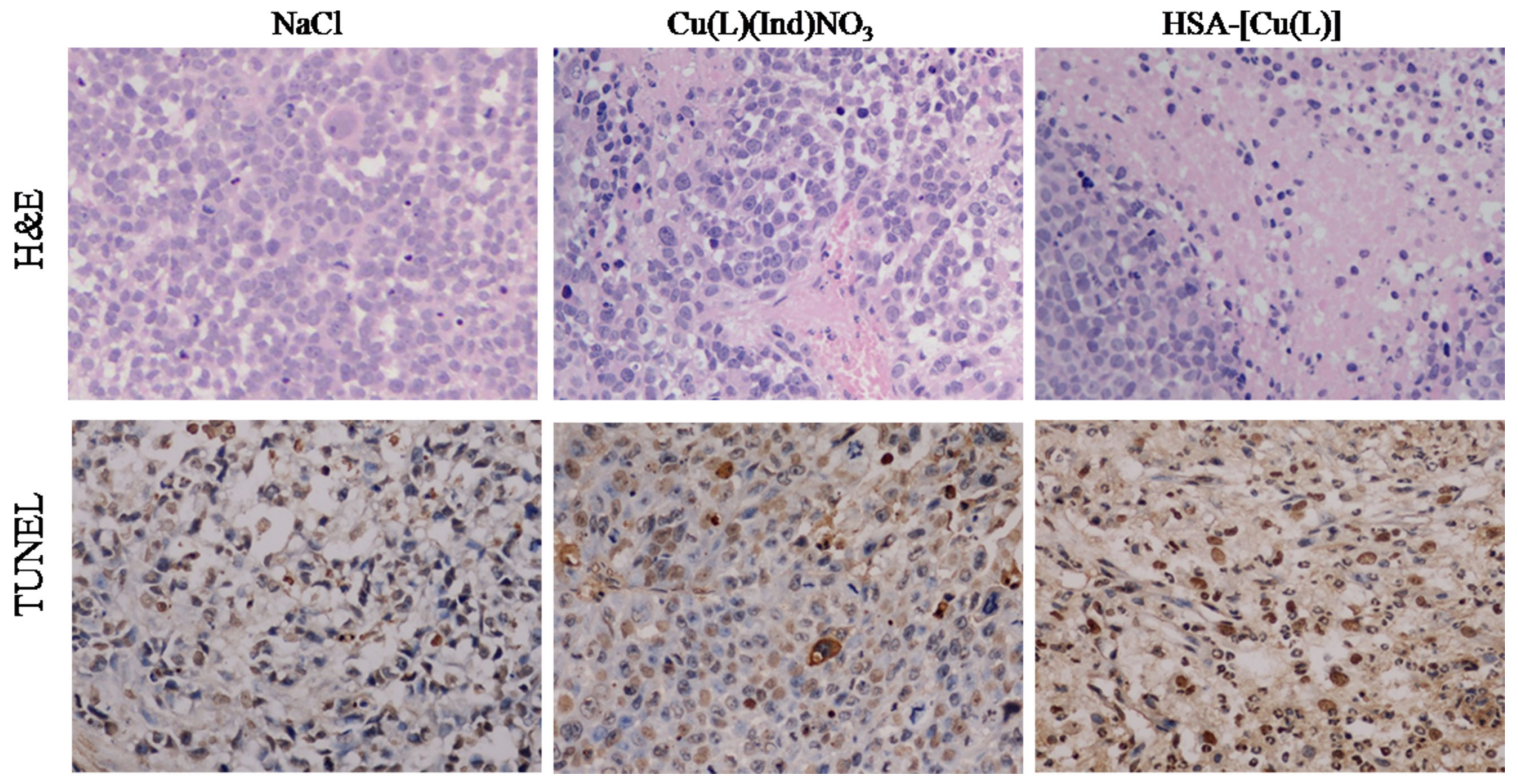

Figure 4: A. Tumors are sectioned and stained with H\&E (magnification $\times 400)$. B. Apoptotic cells were detected in xenograft tumor tissue using the TUNEL assay. 
cell atrophy, hepatic cord loss, and mild steatosis) and kidneys (focal abnormalities) was observed in mice treated with $\left[\mathrm{Cu}(\mathrm{L})(\mathrm{Ind}) \mathrm{NO}_{3}\right]$; this damage was greatly decreased in mice treated with the HSA complex. Interestingly, the hearts of mice in all the treatment groups showed normal histology.

\section{In vivo selectivity of the HSA complex}

To evaluate whether the HSA complex selectively accumulated into MCF-7 tumor cells in vivo, we tested $\mathrm{Cu}$ concentration in the tumors of mice at the end of the experimental period. Results of inductively coupled plasma atomic emission spectrometry (ICP-AES) showed that $\mathrm{Cu}$ concentration in the MCF-7 tumors of mice treated with the HSA complex was approximately 1.5fold higher than that in the tumors of mice treated with $\left[\mathrm{Cu}(\mathrm{L})(\mathrm{Ind}) \mathrm{NO}_{3}\right]$ (Figure 6A). These data suggested that the HSA complex selectively accumulated in tumors. Furthermore, our data indicated that the HSA complex decreased $\mathrm{Cu}$ compound accumulation in the liver and kidney (Figure 6A).

\section{Release of Cu compound from the HSA complex}

It remains unclear how the $\mathrm{Cu}$ compound is released from the HSA- $[\mathrm{Cu}(\mathrm{L})]$ complex under different environments. To address this issue, we simulated the in vivo environment and measured the release of the $\mathrm{Cu}$ compound from the HSA in buffers with $\mathrm{pH} 4.7$ and 7.4 (Figure 6B) $[56,57]$. Our results indicate that approximately $5 \%$ of the loaded $\mathrm{Cu}$ compound was released from the HSA complex within 48hours at $\mathrm{pH}$ 7.4 while up to $80 \%$ of the loaded $\mathrm{Cu}$ compound was released from the HSA complex at $\mathrm{pH}$ 4.7. Additionally, the binding affinity of $\left[\mathrm{Cu}(\mathrm{L})(\mathrm{Ind}) \mathrm{NO}_{3}\right]$ to the HSA carrier at $\mathrm{pH} 7.4\left(K=7.03 \pm 0.06 \times 10^{6} \mathrm{M}^{-1}\right)$ was significantly stronger than that at $\mathrm{pH} 4.7\left(K=4.73 \pm 0.03 \times 10^{4} \mathrm{M}^{-1}\right)$. These results strongly suggest that the $\mathrm{Cu}$ compound was bound weakly to and could be released more easily from the HSA complex in an acidic environment.

\section{Possible anticancer mechanism of $[\mathrm{Cu}(\mathrm{L})(\mathrm{Ind})$ $\left.\mathrm{NO}_{3}\right]$ and the HSA complex}

Most previously outlined metal compounds are assumed to encourage cell death by damaging cell DNA $[58,59]$. We therefore investigated the expression of biomarkers associated with that DNA damage pathway. MCF-7 cells were incubated with the $\left[\mathrm{Cu}(\mathrm{L})(\mathrm{Ind}) \mathrm{NO}_{3}\right]$ compound and the HSA complex (HSA- $[\mathrm{Cu}(\mathrm{L})]$ ) at an identical concentration for 24 hours. Untreated MCF-7 cells were used as a negative control. The Western blot data show that the phosphorylated forms of CHK1, CHK2, $\mathrm{H} 2 \mathrm{AX}(\gamma \mathrm{H} 2 \mathrm{AX})$ and p53 (Ser15) proteins expression are up-regulated slightly by $\left[\mathrm{Cu}(\mathrm{L})(\mathrm{Ind}) \mathrm{NO}_{3}\right]$ compound in
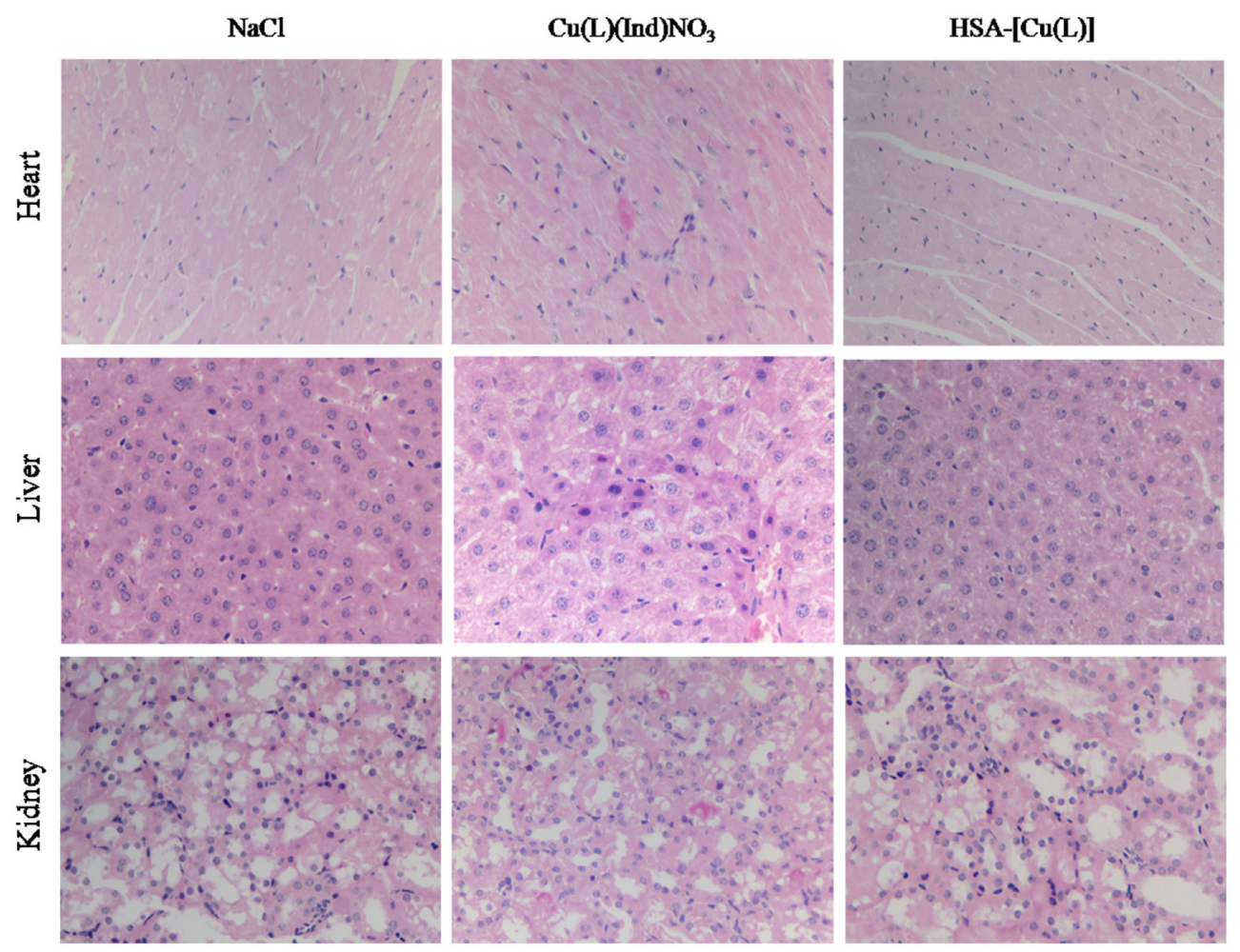

Figure 5: H\&E staining analysis of organs sections treated with various treatments (magnification $\times 400)$. 
comparison with the control, whereas the expressions of the phosphorylated proteins are markedly enhanced by the HSA complex (Figure 7A). This result indicates that the HSA complex kill cells by damaging DNA [60-62].

Cell cycle arrest and apoptosis are two of the most common cellular response to DNA damage [63], and we therefore monitored features related to these pathways. As shown in Figure 7B, the present outcomes show that the $\left[\mathrm{Cu}(\mathrm{L})(\mathrm{Ind}) \mathrm{NO}_{3}\right]$ compound and the HSA-[Cu(L)] cause an accumulation of cells in the G2/M phase of the cell growth cycle. Advancement through the cell cycle is tightly controlled by cyclin complexes and cyclindependent kinases (CDKs) at the different phases [64]. To continue investigating the mechanisms that took part in the HSA- $[\mathrm{Cu}(\mathrm{L})]$ anticancer actions, CDK1 and cyclin B1 were studied. Compared with the vehicle-treated control, the expression level of cyclin B1 was decreased by the $\left[\mathrm{Cu}(\mathrm{L})(\mathrm{Ind}) \mathrm{NO}_{3}\right]$ compound and the HSA- $[\mathrm{Cu}(\mathrm{L})]$, especially for the HSA-[Cu(L)]. Similar outcomes were also noted for $\mathrm{CDK} 1$ after treatment with $\left[\mathrm{Cu}(\mathrm{L})(\mathrm{Ind}) \mathrm{NO}_{3}\right]$ compound and the HSA-[Cu(L)] (Figure 7C).
Many metal drugs generally exert their cytotoxic effects through apoptosis. In this study, the FITCAnnexin V/PI method was utilized to figure out whether the degradation of MCF-7 cells incubated with the HSA- $[\mathrm{Cu}(\mathrm{L})]$ was induced by apoptosis. Results from Annexin V-FITC/PI staining shows that the percentage of MCF-7 cell apoptosis is $23.4 \%$ for the $[\mathrm{Cu}(\mathrm{L})(\mathrm{Ind})$ $\left.\mathrm{NO}_{3}\right]$ compound and $33 \%$ for the HSA- $[\mathrm{Cu}(\mathrm{L})]$ (Figure 8A). Apoptotic cells usually demonstrate changes in cell morphology; e.g., blebbing, nuclear fragmentation and chromatin condensation. MCF-7 cells treated with $\left[\mathrm{Cu}(\mathrm{L})(\mathrm{Ind}) \mathrm{NO}_{3}\right]$ compound display morphologic signs of apoptosis, whereas cells treated with the HSA- $[\mathrm{Cu}(\mathrm{L})]$ show distinct morphological changes that are characteristic of apoptosis (Figure 8B). Hence, both flow cytometry assay and morphological features provide validation for the apoptosis pathway.

The mitochondrial transmembrane potential $\left(\Delta \psi_{\mathrm{m}}\right)$ regulates the permeability of the mitochondrial pore, which plays a vital role in provoking apoptosis. The changing of mitochondria pore can be shown by several
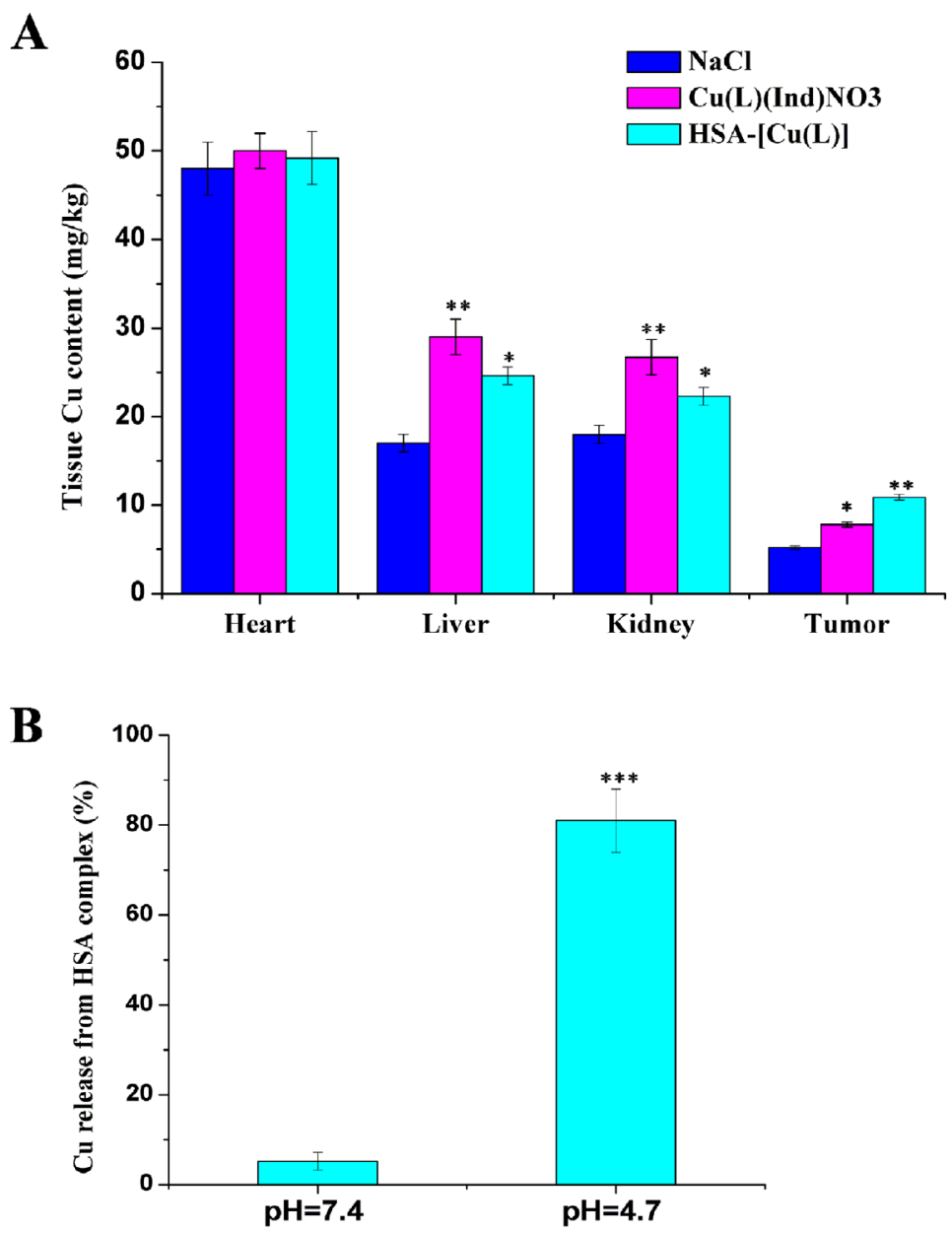

Figure 6: A. Tissue copper of mice after treatment with saline, $\left[\mathrm{Cu}(\mathrm{L})(\mathrm{Ind}) \mathrm{NO}_{3}\right]$ and $\mathrm{HSA}-[\mathrm{Cu}(\mathrm{L})]$. B. The profiles of $\mathrm{Cu}$ release from HSA complex at different $\mathrm{pH}$ (citric-phosphate buffer). Results are the mean $\pm \mathrm{SD}(\mathrm{n}=3):{ }^{*} p<0.05 ; * * p<0.01 ; * * * p<0.001$. 
important events such as the decrease in mitochondrial membrane potential, the emergence of mitochondrial permeability transition, and the release of cytochrome $c$ [65]. To determine whether or not apoptosis induced by $\left[\mathrm{Cu}(\mathrm{L})(\mathrm{Ind}) \mathrm{NO}_{3}\right]$ compound and the HSA-[Cu(L)] is mediated by mitochondrial dysfunction, $\Delta \psi_{\mathrm{m}}$ was examined by flow cytometry using JC-1. As shown in Figure $8 \mathrm{C}$, treatment of MCF-7 cells with $[\mathrm{Cu}(\mathrm{L})(\mathrm{Ind})$ $\left.\mathrm{NO}_{3}\right]$ compound and the $\mathrm{HSA}-[\mathrm{Cu}(\mathrm{L})]$ causes a reduction in $\Delta \psi_{\mathrm{m}}$ to varying amounts, confirming the provocation of mitochondria-mediated apoptosis. Western blot analysis (Figure $8 \mathrm{D}$ ) revealed that $\left[\mathrm{Cu}(\mathrm{L})(\mathrm{Ind}) \mathrm{NO}_{3}\right]$ compound and the HSA- $[\mathrm{Cu}(\mathrm{L})]$ inhibited the expression of Bcl-2 and Bcl-xl (prosurvival Bcl-2 family proteins), and encouraged the expression of $\mathrm{Bcl}-2$ associated death promoter, or $\mathrm{BAD}$. The ratio of $\mathrm{Bcl}-\mathrm{xl} / \mathrm{BAD}$ and $\mathrm{Bcl}-2 / \mathrm{BAX}$ is reduced, suggesting that the $\mathrm{Bcl}-2$ family of proteins regulates the loss of $\Delta \psi_{\mathrm{m}}$. In addition, immunoblotting studies revealed that cytochrome $c$ and cleaved caspase family proteins (cleaved caspase 3, 7 and 9) were enhanced. These data strongly suggest that the $\mathrm{HSA}-[\mathrm{Cu}(\mathrm{L})]$ can effectively trigger mitochondria-mediated apoptosis by regulating the expression of Bcl-2 family proteins compared with $[\mathrm{Cu}(\mathrm{L})$ (Ind) $\mathrm{NO}_{3}$ ].

A Control $\mathrm{Cu}(\mathrm{L})\left(\right.$ Ind) $\mathrm{NO}_{3} \quad \mathrm{HSA}-[\mathrm{Cu}(\mathrm{L})]$

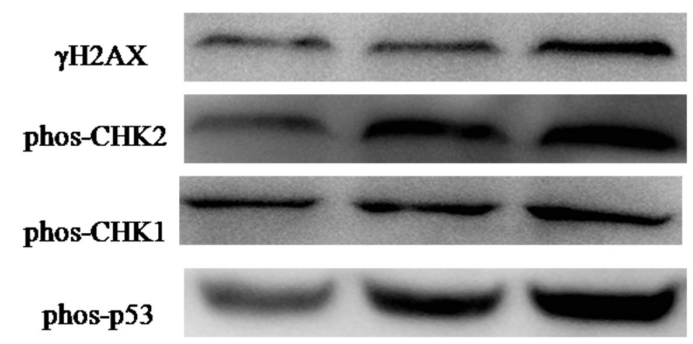

$\beta$-actin

\section{DISCUSSION}

To enhance the in vitro specificity, anticancer and delivery efficiency of $\mathrm{Cu}$-containing agent, we could design $\mathrm{Cu}$ pro-drugs modeled on the structure and behavior of the HSA IIA subdomain. Indeed, our results show that it is feasible to develop $\left[\mathrm{Cu}(\mathrm{L})(\mathrm{Ind}) \mathrm{NO}_{3}\right]$ as a pro-drug by using the special by-products (Lys199 and His242) of the HSA IIA subdomain because the HSA complex structure showed that Lys 199 and His242 replaced indazole and $\mathrm{NO}_{3}^{-}$of $\left[\mathrm{Cu}(\mathrm{L})\left(\right.\right.$ Ind) $\left.\mathrm{NO}_{3}\right]$ and coordinated with $\mathrm{Cu}(\mathrm{II})$. This reaction allows the $\mathrm{Cu}$ compound to bind well to the hydrophobic cavity of the HSA IIA subdomain. Additionally, only a limited amount of $\mathrm{Cu}$ compound (approximately 5\%) was released from the HSA complex at $\mathrm{pH}$ 7.4. In contrast, the binding affinity of $\left[\mathrm{Cu}(\mathrm{L})(\mathrm{Ind}) \mathrm{NO}_{3}\right]$ to the HSA carrier drastically decreased in an acidic environment, and the amount of $\mathrm{Cu}$ compound (approximately 80\%) released from the HSA complex. These results suggested that the HSA complex would be stable in the blood during in vivo circulation and that the $\mathrm{Cu}$ compound would be released after selective accumulation into the acidic lysosomes of cancer cells.

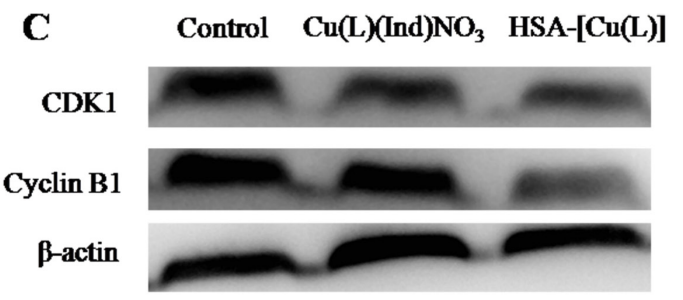

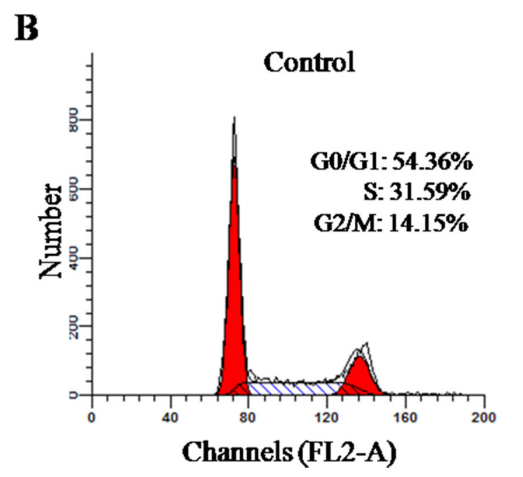
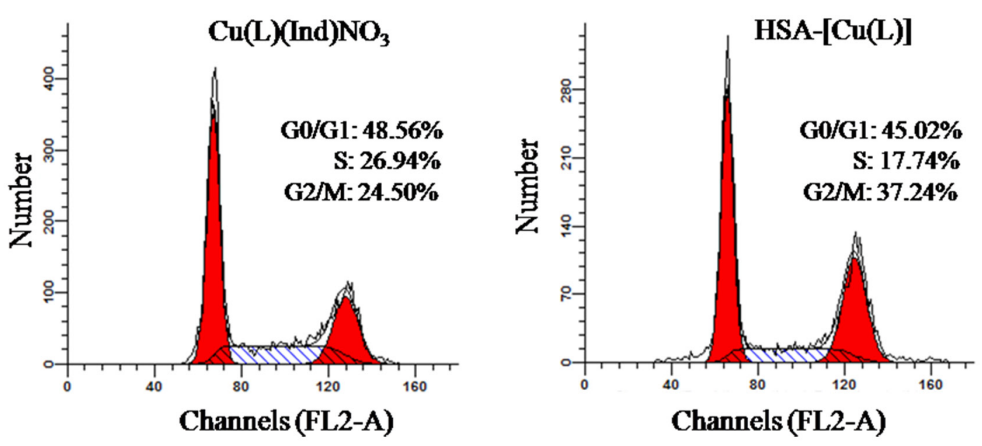

Figure 7: A. Immunoblotting analysis of proteins $(\gamma \mathrm{H} 2 \mathrm{AX}$, phos-CHK1, phos-CHK2 and phos-p53) related to the DNA damage pathway. $\beta$-Actin was assessed as a loading control. B. The cell cycle distribution histograms of MCF-7 cells treated with $\left[\mathrm{Cu}(\mathrm{L})(\mathrm{Ind}) \mathrm{NO}_{3}\right]$ and $\mathrm{HSA}-$ $[\mathrm{Cu}(\mathrm{L})]$ at the same concentration of $1.4 \mu \mathrm{M}$ for $24 \mathrm{~h}$. C. The expression levels of CDK1 and cyclin B1 in MCF-7 cells induced by [Cu(L) (Ind) $\left.\mathrm{NO}_{3}\right]$ and HSA-[Cu(L)] at the same concentration $(1.4 \mu \mathrm{M})$, determined by Western blot analysis. Cells untreated are used as a control, and $\beta$-actin is the loading control. Each experiment group is repeated three times. 
In vivo therapeutic efficiency of the HSA complex was evaluated by considering 3 aspects, namely, selectivity, associated side effects, and TIR. The TIR of the HSA complex reached $64.6 \%$ and was approximately 1.8-times higher than that of $\left[\mathrm{Cu}(\mathrm{L})(\mathrm{Ind}) \mathrm{NO}_{3}\right](35.2 \%)$. Mice treated with the HSA complex showed no significant reduction in their body weight, while those treated with $\left[\mathrm{Cu}(\mathrm{L})(\mathrm{Ind}) \mathrm{NO}_{3}\right]$ showed a significant weight loss. H\&E staining indicated that damage to the liver and kidneys was greatly reduced in mice treated with the HSA complex in comparision with that in mice treated with $[\mathrm{Cu}(\mathrm{L})(\mathrm{Ind})$ $\mathrm{NO}_{3}$ ]. Importantly, results of ICP-AES showed that the HSA complex facilitated the accumulation of the $\mathrm{Cu}$ compound into tumors in vivo. Taken together, the results of breast cancer xenograft experiments in mice indicated that the HSA complex was associated with lesser side effects and better antitumor activity and resulted in the selective accumulation of the $\mathrm{Cu}$ compound in tumor cells compared with the free $\mathrm{Cu}$ compound.

Why does the HSA complex showed stronger in vivo selectivity toward tumor cells compared with the $\mathrm{Cu}$ compound alone. It is attributable to the unique characteristics of the tumor tissue and the HSA carrier (Figure 9A) [28]. Unlike blood vessels in most normal tissues, ongoing angiogenesis in tumor tissues produces vascular gaps ( $\geq 200 \mathrm{~nm}$ ) between adjacent endothelial cells [66-68]. HSA (diameter, approximately $15 \mathrm{~nm}$ ) accumulates in the leaky vasculature surrounding tumor cells by the enhanced permeability and retention (EPR) effect and therefore is delivered more preferentially to tumor cells [28]. In contrast, the $\left[\mathrm{Cu}(\mathrm{L})(\mathrm{Ind}) \mathrm{NO}_{3}\right]$ compound penetrates both tumor and normal cells, but the $\left[\mathrm{Cu}(\mathrm{L})(\mathrm{Ind}) \mathrm{NO}_{3}\right]$ agent, as a small molecule, was shown to be rapidly cleared from the tumor interstitium $[69,70]$. This unique property of the HSA carrier supports naked $\mathrm{Cu}$ compound to decrease cytotoxicity against normal cells and enhance cytotoxicity against cancer cells. In addition, the tumor endothelium expresses 2 albumin-binding proteins, namely, secreted protein acidic and rich in cysteine (SPARC) and gp60 receptor [7173], which may facilitate the uptake and retention of the HSA complex in the tumor interstitium. Subsequently, HSA complex enters into the tumor cells by endocytosis [74]. The $\mathrm{Cu}$ compound released from the HSA complex then eliminates cancer cells, possibly through diverse anticancer mechanisms (Figure 9B) that induce DNA damage (Figure 7A), resulting in activation of the p53 pathway, cell cycle arrest at the G2/M phase (Figure 7B), and mitochondria-mediated apoptosis by regulation of the expression of Bcl-2 family proteins (Figure 8).
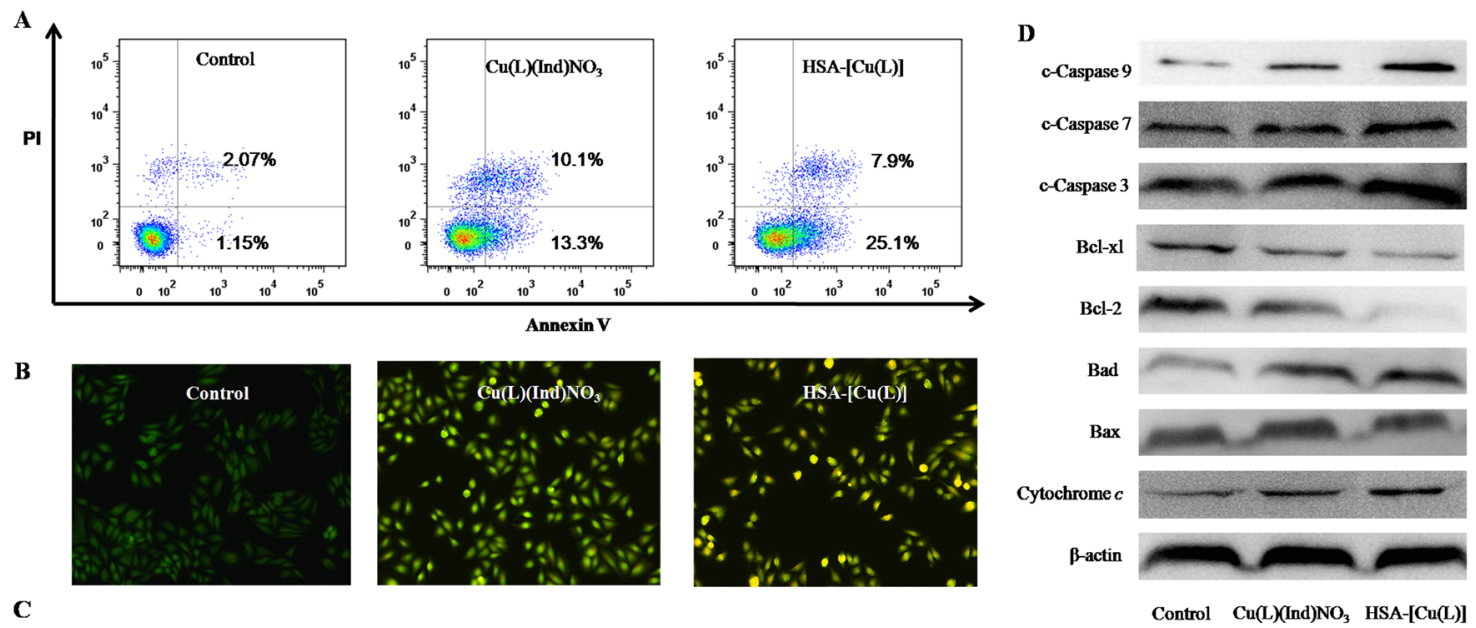

C

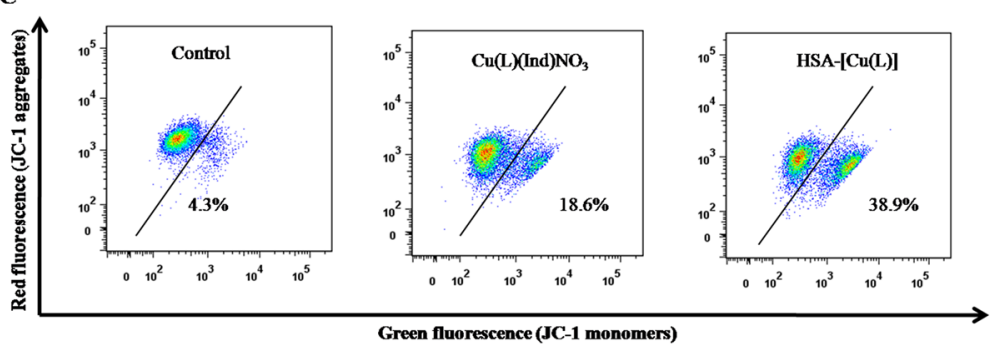

Control $\quad \mathrm{Cu}(\mathrm{L})(\mathrm{Ind}) \mathrm{NO}_{3} \quad \mathrm{HSA}-[\mathrm{Cu}(\mathrm{L})]$

Figure 8: A. Representative dot plots of PI and Annexin V double staining on the MCF-7 cells in the presence of the indicated concentration $(1.4 \mu \mathrm{M})$ of $\left[\mathrm{Cu}(\mathrm{L})(\mathrm{Ind}) \mathrm{NO}_{3}\right]$ and $\mathrm{HSA}-[\mathrm{Cu}(\mathrm{L})]$. B. Representative images of $\mathrm{AO} / \mathrm{EB}$ double stained MCF-7 cells after treatment with complexes $\left[\mathrm{Cu}(\mathrm{L})(\mathrm{Ind}) \mathrm{NO}_{3}\right]$ and $\mathrm{HSA}-[\mathrm{Cu}(\mathrm{L})]$ the indicated concentration $(1.4 \mu \mathrm{M})$. C. Effects of $\left[\mathrm{Cu}(\mathrm{L})(\mathrm{Ind}) \mathrm{NO}_{3}\right]$ and $\mathrm{HSA}-[\mathrm{Cu}(\mathrm{L})]$ at the same concentration $(1.4 \mu \mathrm{M})$ on mitochondrial membrane potential analyzed by JC-1 staining and flow cytometry. D. The expression levels of the Bcl-2 family proteins and the caspase family members in Bel-7402 cells induced by $\left[\mathrm{Cu}(\mathrm{L})(\mathrm{Ind}) \mathrm{NO}_{3}\right]$ and $\mathrm{HSA}-[\mathrm{Cu}(\mathrm{L})]$ at the same concentration $(1.4 \mu \mathrm{M})$ for $24 \mathrm{~h}$. 
In conclusion, owing to Lys 199 and His242 of HSA replacing with leaving groups of $\mathrm{Cu}$ pro-drug and coordinating with $\mathrm{Cu}^{2+}$, the delivery efficiency and anticancer activity of $\mathrm{Cu}$ compound has been improved through tighter binding to the IIA subdomain of HSA, and by selectively accumulating in tumor tissue. Compared to the $\mathrm{Cu}$ compound alone, the HSA complex showed better tolerance, higher drug accumulation in tumor tissues, and lower toxicity, indicating that it had superior antitumor activity and was associated with lesser side effects. These results suggested that the pro-drug strategy with an HSA carrier for the i.v. administration of novel, active aroylhydrazone Schiff base-containing $\mathrm{Cu}(\mathrm{II})$ pro-drugs may be a novel and effective approach for targeted cancer therapy.

\section{MATERIALS AND METHODS}

Human serum albumin (fatty acid content < $0.05 \%$, catalogue number A3782) was bought from the Sigma Chemical Company and used without additional purification. All other chemicals and solvents utilized were undiluted and accessible at commercial sources. Elemental analyses ( $\mathrm{C}, \mathrm{N}$ and $\mathrm{H}$ ) of all complexes were performed on a PerkinElmer series II CHNS/O 2400 analyzer. Infrared (IR) spectra were recorded using $\mathrm{KBr}$ pellets (4000-400 $\mathrm{cm}^{-1}$ ) on a Nexus 870 FT-IR spectrophotometer. UVvisible spectra were measured at room temperature using a Cary 1E UV-visible spectrophotometer in the 200-800 nm range.

$\mathbf{A}$

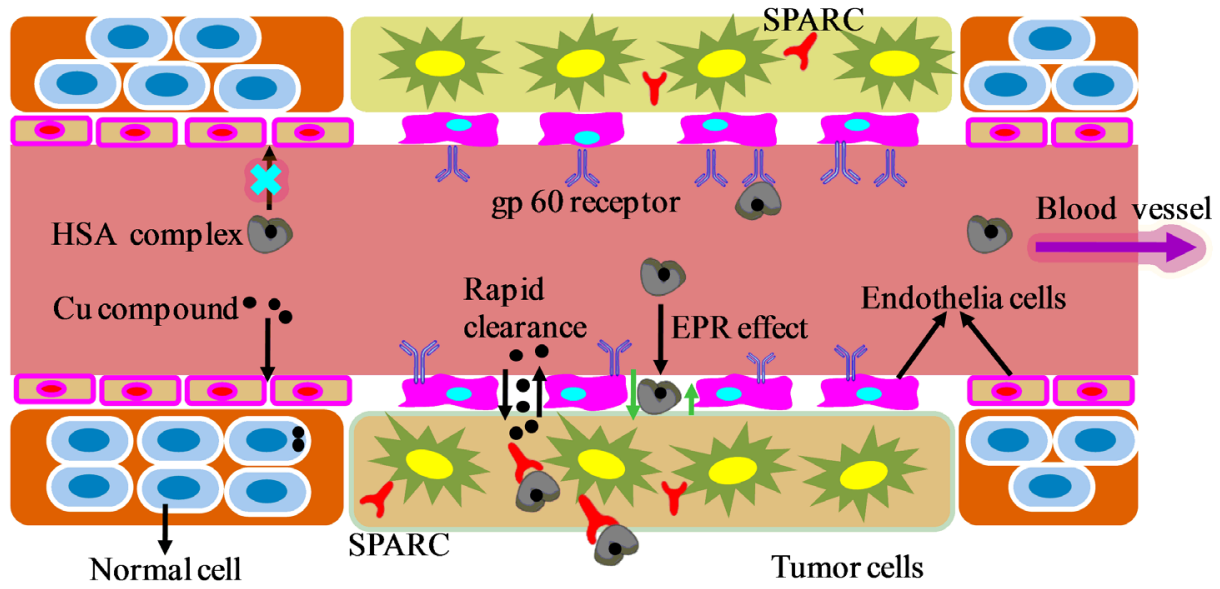

B

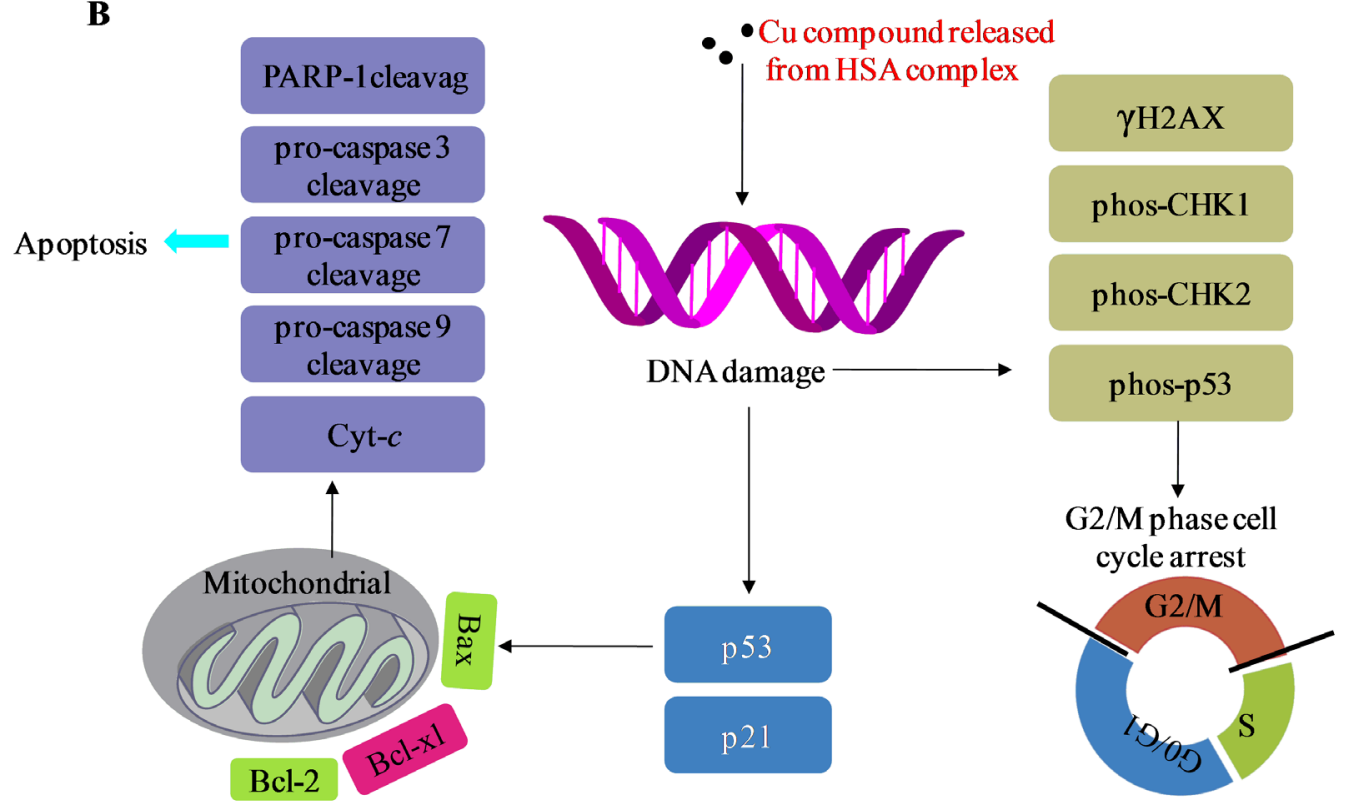

Figure 9: A. General schematics of the delivery process of HSA complex through normal and cancerous tissues. B. Proposed cellular mechanism of action. Abbreviations: SPARC, secreted protein acidic and rich in cysteine; EPR effect, the enhanced permeability and retention effect. 


\section{Synthesis and characterization of $[\mathrm{Cu}(\mathrm{L})(\mathrm{Ind})$ $\mathrm{NO}_{3}$ l}

(E)- $N$ '-(5-bromo-2-hydroxybenzylidene) benzohydrazide Schiff base ligand (HL) was synthesized according to previous reported methods [52].

$\mathrm{Cu}\left(\mathrm{NO}_{3}\right)_{2} \cdot 3 \mathrm{H}_{2} \mathrm{O}(0.48 \mathrm{~g}, 2 \mathrm{mmol})$ was dissolved in $15 \mathrm{~mL}$ of methanol. To this, a solution of HL ligand ( 0.64 $\mathrm{g}, 2 \mathrm{mmol})$ and indazole $(0.23 \mathrm{~g}, 2 \mathrm{mmol})$ in methanol $(15 \mathrm{~mL})$ was added. The combined solutions were stirred at room temperature for 24 hours to result in a celadon solution and then filtered. The filtrate was kept uncovered for a week, and formed blue block crystals. The crystals were isolated, washed three times with distilled water and dried in a vacuum desiccator containing anhydrous $\mathrm{CaCl}_{2}$. Yield: $820 \mathrm{mg}(73 \%)$. Anal. Calcd for $\mathrm{C}_{21} \mathrm{H}_{16} \mathrm{BrCuN}_{5} \mathrm{O}_{5}$ (561.84): C, 44.79; H, 2.87 and N, 12.46. Found: C, 44.93; $\mathrm{H}, 2.89$ and $\mathrm{N}, 12.27$. IR $\left(\mathrm{KBr}, \mathrm{cm}^{-1}\right): 1618 \mathrm{i}(\mathrm{C}=\mathrm{N}) ; 567$, $514,459,445 \mathrm{i}(\mathrm{Cu}-\mathrm{N} / \mathrm{Cu}-\mathrm{O})$.

\section{Structure determination of $\mathbf{C u}$ (II) compound}

A Bruker APEX CCD X-ray diffractometer controlled by the APEX2 software was utilized to collect the diffraction of graphite-monochromated $\mathrm{Mo}-\mathrm{K} \alpha(\lambda=$ $0.71073 \AA$ ) radiation from the crystal at room temperature. Empirical adsorption corrections were applied to all data using SADABS. The structures were solved by direct methods and improved against $F^{2}$ by full-matrix leastsquares methods using the SHELXTL version 5.1 [75]. All of the non-hydrogen atoms were improved anisotropically. Hydrogen atoms were placed at calculated positions and restricted to ride on their parent atoms. Crystallographic data for compound $\left[\mathrm{Cu}(\mathrm{L})(\mathrm{Ind}) \mathrm{NO}_{3}\right]$ data are provided in Supplementary Tables S1 and S2. Crystallographic data for the structural analyses have been deposited at the Cambridge Crystallographic Data Centre, reference number 1418472.

\section{X-ray crystallography of HSA complex}

Palmitic acid (PA) was dissolved in alcohol and diluted to $2.5 \mathrm{mM}$ by $20 \mathrm{mM} \mathrm{pH} 7.5$ potassium phosphate. Fatty acid (FA) free HSA was purified by removing HSA dimers and multimers as published [76]. The complexes of $\mathrm{Cu}(\mathrm{II})$ compounds and HSA were prepared by mixing $100 \mu \mathrm{L}$ HSA $(100 \mathrm{mg} / \mathrm{mL}), 380 \mu \mathrm{L}$ PA $(2.5 \mathrm{mM})$ and 90 $\mu \mathrm{L} \mathrm{Cu}$ compound $(5 \mathrm{mM})$ overnight. The mixture was then concentrated to $100 \mathrm{mg} / \mathrm{ml}$ with a Millipore spin filter (10000 Da cutoff). Crystallization was performed by setting drop vapor diffusion at room temperature. An equal volume of the HSA complex was mixed with the reservoir solution, consisting of $28-32 \%(\mathrm{w} / \mathrm{v})$ polyethylene glycol $3350,50 \mathrm{mM}$ potassium phosphate (pH 7.5), 5\% glycerol, and 4\% DMSO. Crystals were directly selected from the drop solution and then frozen in liquid nitrogen.

X-ray diffraction data were collected under cryoconditions $(100 \mathrm{~K})$ using the Shanghai Synchrotron Radiation Facility. The data were integrated and scaled with HKL2000. The data set obtained from the HSA complex was processed in space group $P 1$. The structure of the HSA complex was solved by molecular replacement with the AMORE program using the HSA-MYR structure (PDB code 1BJ5) stripped of its ligands as the model. The model was initially enhanced using a rigid body protocol in CNS and then subjected to cycles of positional and $B$-factor refinement before the calculation of the initial $2 F_{\mathrm{o}}-F_{\mathrm{c}}$ and $F_{\mathrm{o}}-F_{\mathrm{c}}$ maps was set. These maps were used to guide the position of the fatty acid and drug ligands and to make manual changes to the protein before performing more cycles of refinement. Figures representing the structure were prepared by PyMOL [77]. Data unit cell parameters and collection details are given in Table 3.

\section{Cell culture}

MCF-7 human breast cancer cell lines, MCF-7/ADR drug-resistant cells, and WI-38 normal lung fibroblast cells (purchased from the American Type Culture Collection and the German Collection of Microorganisms and Cell Cultures) were cultured in Culture medium DMEM or RPMI 1640. The culture mediums contain $10 \%$ fetal bovine serum (FBS), $50 \mathrm{U} / \mathrm{mL}$ of penicillin, and $50 \mathrm{mg} / \mathrm{mL}$ of streptomycin at $37^{\circ} \mathrm{C}$ under a humidified atmosphere containing $5 \% \mathrm{CO}_{2}$.

\section{Cytotoxicity assay (MTT)}

The colorimetric MTT assay was used to determine the toxicity of the compound $\left[\mathrm{Cu}(\mathrm{L})(\mathrm{Ind}) \mathrm{NO}_{3}\right]$ and its HSA complex. One hundred microliters of cell suspension at a density of $5 \times 10^{4}$ cells per $\mathrm{mL}$ was seeded in 96-well plates and incubated for 24 hours at $37^{\circ} \mathrm{C}$ in $5 \% \mathrm{CO}_{2}$. Then the medium was replaced with a replacement medium comprised of $10 \%$ FBS containing the compounds at various concentrations and incubated at $37^{\circ} \mathrm{C}$ under conditions of $5 \% \mathrm{CO}_{2}$. The final concentration of DMSO in each well was $0.5 \%$ and this amount was present in the untreated control as well. After 48 hours, $20 \mu \mathrm{L}$ of $5 \mathrm{mg} / \mathrm{mL}$ MTT assay stock solution in PBS was added to each well, and the plate was incubated for another 4 hours. Then, the obtained blue formazan crystals were dissolved in $200 \mu \mathrm{L}$ well ${ }^{-1}$ DMSO. The absorbance was read by an enzyme labeling instrument (Infinite M2000) with a $570 / 630 \mathrm{~nm}$ double wavelength measurement. The cytotoxicity was measured byte percentage of cell survival compared with the negative control. The final $\mathrm{IC}_{50}$ values were calculated by the Bliss method $(n=5)$. Each test was repeated in at least three independent experiments. 
Table 3: Data collection statistics and crystallographic analysis of HSA complex

$\begin{array}{lc}\text { Data collection } & P 1 \\ \text { Space group } & 95.46,95.64,38.50 \\ \text { Cell parameters, } a, b, c(\AA) & 104.82,90.05,101.86 \\ \text { Cell parameters, } & 27-2.3 \\ \text { Resolution range }(\AA) & 4.1 \\ \text { Data redundancy } & 98 \%(98.7 \%) \\ \text { Completeness }(\%)^{\mathrm{a}} & 14.1(4.4) \\ I / \sigma & 7.5 \%(24.4 \%) \\ R_{\text {merge }}(\%)^{\mathrm{b}} & \\ \text { Model refinement } & 24.68 \% \\ R_{\text {model }}(\%)^{\mathrm{c}} & 29.96 \% \\ R_{\text {free }}(\%)^{\mathrm{d}} & 0.008 \AA \\ \text { r.m.s. deviation from ideal bond lengths } & 1.175 \\ \text { r.m.s. deviation from ideal angles }\left(^{\circ}\right) & \end{array}$

a Values for the outermost resolution shell are given in parentheses.

${ }^{\mathrm{b}} R_{\text {merge }}=100 \times \Sigma_{\mathrm{h}} \Sigma_{\mathrm{j}} \mid \mathrm{I}_{\mathrm{hj}}-\mathrm{I}_{\mathrm{h}} / \Sigma_{\mathrm{h}} \Sigma_{\mathrm{j}} \mathrm{I}_{\mathrm{hj}}$ where $\mathrm{I}_{\mathrm{h}}$ is the weighted mean intensity of the symmetry-related refractions $\mathrm{I}_{\mathrm{hj}}$.

${ }^{\mathrm{c}} R_{\text {model }}=100 \times \Sigma_{\text {hkl }}\left|\mathrm{F}_{\text {obs }}-\mathrm{F}_{\text {calc }}\right| / \Sigma_{\text {hkl }} \mathrm{F}_{\text {obs }}$ where $\mathrm{F}_{\text {obs }}$ and $\mathrm{F}_{\text {calc }}$ are the observed and calculated structure factors, respectively.

${ }^{\mathrm{d}} R_{\text {free }}$ is the $R_{\text {model }}$ calculated using a randomly selected 5\% sample of reflection data omitted from the refinement.

\section{In vivo animal studies}

All animal experiments were performed in compliance with the Animal Management Rules of the Ministry of Health of the People's Republic of China (document NO. 55, 2001) and the guidelines for the Care and Use of the University of Jinan Ethics Committee. Female NOD/SCID mice were obtained from Beijing HFK Bioscience Co., Ltd.

\section{Acute toxicity study}

The acute toxicity of the $\left[\mathrm{Cu}(\mathrm{L})(\mathrm{Ind}) \mathrm{NO}_{3}\right]$ and HSA complex were assessed on normal mice as method described previously [78]. Briefly, 24 healthy Kunming mice (aged 3 4 weeks, weighed 18 22 g) were split into three groups, with 8 mice in each group. Free $\mathrm{Cu}$ compound and HSA complex were given to the different groups of mice at a dose of $13 \mu \mathrm{mol} \mathrm{Cu} / \mathrm{kg}$ body weight (i.v.). Saline $(\mathrm{NaCl})$ was administered to the control group. Blood samples from each group of mice were drawn 3 days post-injection to prepare the serum samples. At this juncture the serum biochemical parameters of alanine aminotransferase (ALT), aspartate aminotransferase (AST), blood urea nitrogen (BUN) and creatinine kinase (CK) were determined. Finally, the heart, liver and kidney were sectioned for histopathological analysis with hematoxylin and eosin (H\&E) staining.

\section{In vivo antitumor activity study}

The female nude mice were injected subcutaneously in the right flank region with $200 \mu \mathrm{L}$ of cell suspension containing $5 \times 10^{6} \mathrm{MCF}-7$ cells. $\beta$-Estradiol cypionate
$(3 \mathrm{mg} / \mathrm{kg}$ ) was administered i.m. every 7 days. When the tumour volume was approximately $100 \mathrm{~mm}^{3}$ for antitumour activity study, the mice were randomly divided into 3 groups, 8 animals in each group. The MCF-7 tumor-bearing mice were intravenously injected with $\mathrm{NaCl}$, free $\mathrm{Cu}$ compound and HSA complex at dose of $2.5 \mu \mathrm{mol} \mathrm{Cu} / \mathrm{kg}$ body weight every 3 days. Each mouse of different group was earmarked and followed individually throughout the whole experiments. The width and length of the tumor and the body weight of mice were measured before every injection by the end of experiment. The volume was calculated based on the following equation: tumor volume $(\mathrm{V})=1 / 2 \times$ length $\times$ width $^{2}$. After 24 days of treatment, mice were euthanized and tumor tissues were excised for histopathological analysis with H\&E staining and TUNEL assay.

\section{Selective of HSA complex in vivo}

At the end of the experiment in vivo, the tumors of mice were homogenized, placed in teflon containers and mineralized in a microwave apparatus under pressure (system Milestone MSL 1200) in the presence of $1 \mathrm{~mL}$ of $30 \%$ hydrogen peroxide and in $7 \mathrm{~mL}$ of concentrated $\mathrm{HNO}_{3}$. The contents of $\mathrm{Cu}$ in mice tumor and major organs were determined using inductively coupled plasma atomic emission spectrometry (ICP-AES).

\section{Cu pro-drug release from HSA complex}

The $\mathrm{Cu}$ (II) compound release from HSA complex was studied by dialyzing HSA complex at $\mathrm{pH} 4.7$ and 7.4 buffers (citric-phosphate buffers) to simulate cell matrix and interstitial space environment, respectively [56, 
57]. Briefly, $2 \mathrm{~mL}$ HSA complex suspension in dialysis pocket were dispersed in tube containing $40 \mathrm{~mL} \mathrm{pH}$ 4.7 and 7.4 buffers for $48 \mathrm{~h}$, respectively. The amount of $\mathrm{Cu}$ (II) compound released from the HSA complex was determined by graphite furnace atomic absorption spectrometer (GF-AAS).

\section{Apoptosis by flow cytometry}

The assay was carried out according to the manufacturer's directions for the Annexin V-FITC Apoptosis Detection Kit (Abcam). Briefly, MCF-7 cells seeded into 6-well plates were exposed to the tested compounds at the indicated concentrations for 12 hours. MCF-7 cells without the treatment were used as a control. The cells were then harvested and re-suspended in 500 $\mu \mathrm{L}$ annexin-binding buffer. Next, the cell suspension was stained with $5 \mu \mathrm{L}$ annexin $\mathrm{V}$ and $5 \mu \mathrm{L}$ PI at room temperature with no light source for 15 minutes, and then analyzed immediately by flow cytometry (FACScan, Bection Dickinson, San Jose, CA).

\section{Acridine orange/ethidium bromide (AO/EB) double staining}

MCF-7 cells were treated with $\left[\mathrm{Cu}(\mathrm{L})(\mathrm{Ind}) \mathrm{NO}_{3}\right]$ compound $(1.4 \mu \mathrm{M})$ and HSA complex $(1.4 \mu \mathrm{M})$ for 12 $\mathrm{h}$, and then washed once with ice-cold PBS and fixed with $4 \%$ paraformalclehyde. Cells were washed with ice-cold PBS twice, stained with a medium containing AO/EB solution $(100 \mu \mathrm{g} / \mathrm{mL}$ AO, $100 \mu \mathrm{g} / \mathrm{mL}$ EB) in the dark for 10 min. After washing the cells twice with PBS, the cells with observed morphological change were obtained under a reflected fluorescence microscope (Nikon MF30 LED, Japan).

\section{Cell cycle distribution analysis}

Cell cycle distribution was analyzed by flow cytometry and PI staining. Briefly, MCF-7 cells were treated with $\left[\mathrm{Cu}(\mathrm{L})(\mathrm{Ind}) \mathrm{NO}_{3}\right]$ compound $(1.4 \mu \mathrm{M})$ and HSA complex $(1.4 \mu \mathrm{M})$. For cell cycle analysis, treated cells were collected, washed twice with ice-cold PBS and fixed with $70 \%$ ethanol at $4{ }^{\circ} \mathrm{C}$ overnight. Next, cells were treated with Rnase A (100 $\mu \mathrm{g} / \mathrm{ml})$ for 30 minutes at $37^{\circ} \mathrm{C}$, followed by PI staining for 30 minutes in the dark. The cell cycle was analyzed by flow cytometry (FACScan, Bection Dickinson, San Jose, CA).

\section{The change of mitochondrial membrane potential assay}

JC-1 probe (Beyotime, Haimen, China) was employed to measure mitochondrial depolarization in MCF-7 cells. The cells were treated with the $[\mathrm{Cu}(\mathrm{L})$ (Ind) $\mathrm{NO}_{3}$ ] compound $(1.4 \mu \mathrm{M})$ and HSA complex $(1.4$ $\mu \mathrm{M})$ for $12 \mathrm{~h}$ and collected by centrifugation. The cells were resuspended and stained with $0.5 \mathrm{~mL}$ of JC-1 (10 $\mu \mathrm{g} / \mathrm{mL}$ ) stock solution for $30 \mathrm{~min}$ at $37^{\circ} \mathrm{C}$ in the dark. Subsequently, the fluorescence of separated cells was detected with a flow cytometer (FACScan, Bection Dickinson, San Jose, CA).

\section{Western blot analysis}

MCF-7 cells were seeded in $3.5 \mathrm{~cm}$ dishes at a density of $5.0 \times 10^{5}$ cells/well in $5 \mathrm{~mL}$ of complete DMEM and allowed to attach for $24 \mathrm{~h}$ at $37^{\circ} \mathrm{C}$. The cells were treated with $\left[\mathrm{Cu}(\mathrm{L})(\mathrm{Ind}) \mathrm{NO}_{3}\right]$ and HSA complex at indicated concentrations for $24 \mathrm{~h}$. The cells untreated were used as a negative control. After treatment for $24 \mathrm{~h}$, the cells were harvested and washed with ice-cold PBS three times, and then they were lysed in radioimmunoprecipitation assay (RIPA) buffer supplemented with inhibitors of proteases and inhibitor of proteases and inhibitor of phosphatases sodium orthovanadate. The protein concentration of the supernatant was determined by BCA (bicinchoninic acid) assay. Equal amounts of cellular total proteins were separated on 10\% SDS-polyacrylamide gel electrophoresis and then transferred onto polyvinylidene difluoride membranes (Millipore, MA, USA) and blocked with 5\% nonfat milk in TBST buffer $(20 \mathrm{mM}$ Tris, $\mathrm{pH} 8.0$, $150 \mathrm{mM} \mathrm{NaCl}$, and $0.05 \%$ Tween 20 ) for $1 \mathrm{~h}$. Then, the membranes were incubated with the $\beta$-actin, CDK1, Cyclin $\mathrm{B}, \gamma \mathrm{H} 2 \mathrm{AX}$, phos-CHK2, phos-CHK1, phos-p53, cleaved caspase-9, cleaved caspase-7, cleaved caspase-3, Bcl-xl, Bcl-2, Bad, Bax and cytochrome $c$ primary antibodies (Cell Signaling Technology and Sigma) overnight at $4^{\circ} \mathrm{C}$. After a subsequent washing step, the membrane is incubated with the appropriate anti-mouse or anti-rabbit secondary antibodies (Cell Signalling Technology) conjugated with horseradish peroxidase for $1 \mathrm{~h}$ at room temperature and washed for three times with TBST. The immunoreactivity was detected using Amersham ECL Plus (Amersham) western blotting detection reagents.

\section{Statistical analysis}

The experiments were repeated three to five times and results were expressed as the mean \pm standard deviation (SD). Student's $t$ test was applied to evaluate the significance of differences measured, and the differences between groups with $p<0.05$ were considered to be significant.

\section{ACKNOWLEDGMENTS}

We are grateful to staff of Shanghai Synchrotron Radiation Facility for their technical assistance in data collection. This work was supported by the Natural Science Foundation of China (31460232, 21431001), the Natural Science Foundation of Guangxi (2014GXNSFDA118016), 
National Basic Research Program of China (IRT1225), Ministry of Education of China (CMEMR2015-A01), Technology division of Guilin (20150102-13) and Guangxi ‘Bagui’ scholar program to ZP Zhou.

\section{CONFLICTS OF INTEREST}

The authors declare no conflicts of interest.

\section{REFERENCES}

1. Mjos KD, Orvig C. Metallodrugs in medicinal inorganic chemistry. Chem Rev. 2014; 114:4540-4563.

2. Muhammad N, Guo Z. Metal-based anticancer chemotherapeutic agents. Curr Opin Chem Biol. 2014; 19:144-153.

3. Lainé AL, Passirani C. Novel metal-based anticancer drugs: a new challenge in drug delivery. Curr Opin Pharmacol. 2012, 12:420-426.

4. Nobili S, Mini E, Landini I, Gabbiani C, Casini A, Messori L. Gold compounds as anticancer agents: chemistry, cellular pharmacology, and preclinical studies. Med Res Rev. 2010; 30:550-580.

5. Jakupec MA, Galanski M, Keppler BK. Tumour-inhibiting platinum complexes-state of the art and future perspectives. Rev Physiol Biochem Pharmacol. 2003; 146:1-54.

6. Medici S, Peana M, Nurchi VM, Lachowicz JI, Crisponi G, Zoroddu MA. Noble metals in medicine: latest advances. Coordin Chem Rev. 2015; 284:329-350

7. Galanski M, Arion VB, Jakupec MA, Keppler BK. Recent developments in the field of tumor-inhibiting metal complexes. Curr Pharm Des. 2003; 9:2078-2089.

8. El Kazzouli S, El Brahmi N, Mignani S, Bousmina M, Zablocka M, Majoral JP. From metallodrugs to metallodendrimers for nanotherapy in oncology: a concise overview. Curr Med Chem. 2012; 9:4995-5010.

9. Sato MR, da Silva PB, de Souza RA, dos Santos KC, Chorilli M. Recent advances in nanoparticle carriers for coordination complexes. Curr Top Med Chem. 2015; 15:287-297.

10. van Rijt SH, Sadler PJ. Current applications and future potential for bioinorganic chemistry in the development of anticancer drugs. Drug Discov Today 2009; 14:1089-1097.

11. Kratz F, Warnecke A. Finding the optimal balance: challenges of improving conventional cancer chemotherapy using suitable combinations with nano-sized drug delivery systems. J Controlled Release. 2012; 164:221-235.

12. He Z, Huang J, Xu Y, Zhang X, Teng Y, Huang C, Wu Y, Zhang X, Zhang H, Sun W. Co-delivery of cisplatin and paclitaxel by folic acid conjugated amphiphilic PEG-PLGA copolymer nanoparticles for the treatment of non-small lung cancer. Oncotarget. 2015; 6:42150-42168. doi: 10.18632/ oncotarget.6243.
13. López-Dávila V, Seifalian AM, Loizidou M. Organic nanocarriers for cancer drug delivery. Curr Opin Pharmacol. $2012 ; 12: 414-419$.

14. Zhang CX, Lippard SJ. New metal complexes as potential therapeutics. Curr Opin Chem Biol. 2003; 7:481-489.

15. Dhar S, Kolishetti N, Lippard SJ, Farokhzad OC. Targeted delivery of a cisplatin prodrug for safer and more effective prostate cancer therapy in vivo. Proc Natl Acad Sci USA. 2011; 108:1850-1855.

16. Allam A, Maigre L, Alimi M, Alves de Sousa R, Hessani A, Galardon E, Pagès JM, Artaud I. New peptides with metal binding abilities and their use as drug carriers. Bioconjug Chem. 2014; 25:1811-1819.

17. Massaguer A, González-Cantó A, Escribano E, Barrabés S, Artigas G, Moreno V, Marchán V. Integrin-targeted delivery into cancer cells of a $\mathrm{Pt}(\mathrm{IV})$ pro-drug through conjugation to RGD-containing peptides. Dalton Trans. 2015; 44:202-212.

18. Dai Y, Xiao H, Liu J, Yuan Q, Ma P, Yang D, Li C, Cheng Z, Hou Z, Yang P, Lin J. In vivo multimodality imaging and cancer therapy by near-infrared light-triggered transplatinum pro-drug-conjugated upconverison nanoparticles. J Am Chem Soc. 2013; 135:18920-18929.

19. Elsadek B, Kratz F. Impact of albumin on drug deliverynew applications on the horizon. J Controled Release. 2012; $157: 4-28$

20. Peters T. All about albumin: biochemistry, genetics and medical applications. Academic Press, San Diego. 1996.

21. Garmann D, Warnecke A, Kalayda GV, Kratz F, Jaehde U. Cellular accumulation and cytotoxicity of macromolecular platinum complexes in cisplatin-resistant tumor cells. J Controlled Release. 2008; 131:100-106.

22. Warnecke A, Fichtner I, Garmann D, Jaehde U, Kratz F. Synthesis and biological activity of water-soluble maleimide derivatives of the anti-cancer drug carboplatin designed as albumin-binding pro-drugs. Bioconjugate Chem. 2004; 15:1349-1359.

23. Pichler V, Mayr J, Heffeter P, Dömötör O, Enyedy ÉA, Hermann G, Groza D, Köllensperger G, Galanksi M, Berger W, Keppler BK, Kowol CR. Maleimide-functionalised platinum(IV) complexes as a synthetic platform for targeted drug delivery. Chem Commun. 2013; 49:2249-2251.

24. Hanif M, Nazarov AA, Legin A, Groessl M, Arion VB, Jakupec MA, Tsybin YO, Dyson PJ, Keppler BK, Hartinger CG. Maleimide-functionalised organoruthenium anti-cancer agents and their binding to thiol-containing biomolecules. Chem Commun. 2012; 48:1475-1477.

25. Ang WH, Daldini E, Juillerat-Jeanneret L, Dyson PJ. Strategy to tether organometallic ruthenium-arene anticancer compounds to recombinant human serum albumin. Inorg Chem. 2007; 46:9048-9050.

26. Stepanenko IN, Casini A, Edafe F, Novak MS, Arion VB, Dyson PJ, Jakupec MA, Keppler BK. Conjugation of organoruthenium(II) 3-(1H-benzimidazol-2-yl) pyrazolo[3,4-b]pyridines and indolo[3,2-d]benzazepines to recombinant human serum albumin: a strategy to 
enhance cytotoxicity in cancer cells. Inorg Chem. 2011; 50:12669-12679.

27. Gou Y, Yang F, Liang H. Designing prodrugs based on special residues of human serum albumin. Curr Top Med Chem. 2015; 9, 996-1008

28. Kratz F. Albumin as a drug carrier: Design of pro-drugs, drug conjugates and nanoparticles. J Controlled Release. 2008; 132:171-183.

29. Ghuman J, Zunszain PA, Petitpas I, Bhattacharya AA, Otagiri M, Curry S. Structural basis of the drug-binding specificity of human serum albumin. J Mol Biol. 2005; 353:38-52.

30. Yang F, Yue J, Ma L, Ma Z, Li M, Wu X, Liang H. Interactive associations of drug-drug and drug-drug-drug with IIA subdomain of human serum albumin. Mol Pharm. 2012; 9:3259-3265.

31. He XM, Carter DC. Atomic structure and chemistry of human serum albumin. Nature. 1992; 358:209-215.

32. Zsila F. Subdomain IB is the third major drug binding region of human serum albumin: toward the three-sites model. Mol Pharm. 2013; 10:1668-1682.

33. Durante S, Orienti I, Teti G, Salvatore V, Focaroli S, Tesei A, Pignatta S, Falconi M. Anti-tumor activity of fenretinide complexed with human serum albumin in lung cancer xenograft mouse model. Oncotarget. 2014; 5:4811-4820. doi: 10.18632/oncotarget.2038.

34. Merlot AM, Sahni S, Lane DJ, Fordham AM, Pantarat N, Hibbs DE, Richardson V, Doddareddy MR, Ong JA, Huang ML, Richardson DR, Kalinowski D.S. Potentiating the cellular targeting and anti-tumor activity of Dp44mT via binding to human serum albumin: two saturable mechanisms of Dp44mT uptake by cells. Oncotarget. 2015; 6:10374-10398. doi: 10.18632/oncotarget.3606.

35. Zhang Y, Ho A, Yue J, Kong L, Zhou Z, Wu X, Yang F, Liang H. Structural basis and anticancer properties of ruthenium-based drug complexed with human serum albumin. Eur J Med Chem. 2014; 86:449-455.

36. Isaacs JT, Dalrymple SL, Rosen DM, Hammers H, Olsson A, Leanderson T. Anti-cancer potency of tasquinimod is enhanced via albumin-binding facilitating increased uptake in the tumor microenvironment. Oncotarget. 2014; 5:8093-8106. doi: 10.18632/oncotarget.2378.

37. Gou Y, Qi J, Ajayi JP, Zhang Y, Zhou Z, Wu X, Yang F, Liang H. Developing Anticancer Copper(II) Pro-drugs Based on the Nature of Cancer Cells and the Human Serum Albumin Carrier IIA Subdomain. Mol Pharm. 2015; 12:3597-3609.

38. Meggers E. Exploring biologically relevant chemical space with metal complexes. Curr Opin Chem Biol. 2007; 11:287-292.

39. Jansson PJ, Sharpe PC, Bernhardt PV, Richardson DR. Novel thiosemicarbazones of the ApT and DpT series and their copper complexes: identification of pronounced redox activity and characterization of their antitumor activity. J Med Chem. 2010; 53:5759-5769.
40. Bernhardt PV, Sharpe PC, Islam M, Lovejoy DB, Kalinowski DS, Richardson DR. Iron chelators of the dipyridylketone thiosemicarbazone class: precomplexation and transmetalation effects on anticancer activity. J Med Chem. 2009; 52:407-415.

41. Lovejoy DB, Jansson PJ, Brunk UT, Wong J, Ponka P, Richardson DR. Antitumor activity of metal-chelating compound Dp44mT is mediated by formation of a redoxactive copper complex that accumulates in lysosomes. Cancer Res. 2011; 71:5871-5880.

42. Tan SJ, Yan YK, Lee PP, Lim KH. Copper, gold and silver compounds as potential new anti-tumor metallodrugs. Future Med Chem. 2010; 2:1591-1608.

43. Santini C, Pellei M, Gandin V, Porchia M, Tisato F, Marzano C. Advances in Copper Complexes as Anticancer Agents. Chem Rev. 2014; 114:815-862.

44. Torre LA, Bray F, Siegel RL, Ferlay J, Lortet-Tieulent J, Jemal A. Global cancer statistics, 2012. CA Cancer J Clin. 2015; 65:87-108.

45. Richardson DR, Tran EH, Ponka P. The potential of iron chelators of the pyridoxal isonicotinoyl hydrazone class as effective antiproliferative agents. Blood. 1995; 86:4295-4306.

46. Green DA, Antholine WE, Wong SJ, Richardson DR, Chitambar CR. Inhibition of malignant cell growth by 311, a novel iron chelator of the pyridoxal isonicotinoyl hydrazone class: effect on the R2 subunit of ribonucleotide reductase. Clin Cancer Res. 2001; 7:3574-3579.

47. Richardson DR, Milnes K. The potential of iron chelators of the pyridoxal isonicotinoyl hydrazone class as effective antiproliferative agents II: the mechanism of action of ligands derived from salicylaldehyde benzoyl hydrazone and 2-hydroxy-1-naphthylaldehyde benzoyl hydrazone. Blood. 1997; 86:3025-3038.

48. Pal A, Biswas B, Mondal SK, Lin C-H, Ghosh R. Copper(II) complexes with neutral Schiff bases: Syntheses, crystal structures and DNA interactions. Polyhedron. 2012; 31:671-675.

49. Wu LM, Teng HB, Feng X C, Ke XB, Zhu QF, Su JT, Xu WJ. Hu XM. Supramolecular Networks in Crystals of Metal(II) Complexes with Water-Soluble Salicylaldehyde2-sulfobenzoylhydrazone Anion Ligand. Cryst Growth Des. 2007; 7:1337-1342.

50. Ranford JD, Vittal JJ, Wang YM. Dicopper(II) Complexes of the Antitumor Analogues Acylbis(salicylaldehyde hydrazones) and Crystal Structures of Monomeric [ $\mathrm{Cu}_{2}$ (1,3-propanedioyl bis(salicylaldehyde hydrazone)) $\left.\left(\mathrm{H}_{2} \mathrm{O}\right)_{2}\right] \cdot\left(\mathrm{ClO}_{4}\right)_{2} \cdot 3 \mathrm{H}_{2} \mathrm{O}$ and Polymeric $\quad\left[\left\{\mathrm{Cu}_{2}(1,6-\right.\right.$ hexanedioyl bis(salicylaldehydehydrazone) $\left.)\left(\mathrm{C}_{2} \mathrm{H}_{5} \mathrm{OH}\right)_{2}\right\}_{\mathrm{m}}$ ] $\left(\mathrm{ClO}_{4}\right)_{2 \mathrm{~m}} \cdot \mathrm{m}\left(\mathrm{C}_{2} \mathrm{H}_{5} \mathrm{OH}\right)$. Inorg Chem. 1998; 37:1226-1231.

51. Iskander MF, Khalil TE, Haase W, Werner R, Svoboda I, Fuess H. Synthesis, magnetochemical studies and X-ray molecular structures of some mononuclear copper(II)-1H-pyrazole adducts and $\operatorname{mono}(\mu-$ pyrazolate) bridged dicopper(II) complexes derived 
from N-salicylidenearoylhydrazines. Polyhedron. 2001; 20:2787-2798.

52. Liu H.-Y, Wang H.-Y, Gao F, Lu Z.-S, Niu D.-Z. 5-Bromosalicylaldehyde benzoyl-hydrazone. Acta Crystallogr., Sect E: Struct Rep Online. 2006; 62:04495.

53. Abou-Zied OK, Al-Shihi OI. Characterization of subdomain IIA binding site of human serum albumin in its native, unfolded, and refolded states using small molecular probes. J Am Chem Soc. 2008; 130:10793-10801.

54. Webb MI, Wu B, Jang T, Chard RA, Wong EW, Wong MQ, Yapp DT, Walsby CJ. Increasing the bioavailability of $\mathrm{Ru}^{\mathrm{III}}$ anticancer complexes through hydrophobic albumin interactions. Chem-Eur J. 2013; 19:17031-17042.

55. Bhattacharya AA, Grüne T, Curry S. Crystallographic analysis reveals common modes of binding of medium and long-chain fatty acids to human serum albumin. J Mol Biol. 2000; 303:721-732.

56. Carreira M, Calvo-Sanjuán R, Sanaú M, Zhao X, Magliozzo RS, Marzo I, Contel M. Cytotoxic hydrophilic iminophosphorane coordination compounds of $\mathrm{d}^{8}$ metals. Studies of their interactions with DNA and HSA. J Inorg Biochem. 2012; 116:204-214.

57. Martínez A, Suárez J, Shand T, Magliozzo RS, SánchezDelgado RA. Interactions of arene-Ru(II)-chloroquine complexes of known antimalarial and antitumor activity with human serum albumin (HSA) and transferrin. J Inorg Biochem. 2011; 105:39-45.

58. Zheng YR, Suntharalingam K, Johnstone TC, Yoo H, Lin W, Brooks JG, Lippard SJ. Pt(IV) prodrugs designed to bind non-covalently to human serum albumin for drug delivery. $\mathrm{J}$ Am Chem Soc. 2014; 136:8790-8798.

59. Suntharalingam K, Johnstone TC, Bruno PM, Lin W. Hemann MT, Lippard SJ. Bidentate ligands on osmium(VI) nitrido complexes control intracellular targeting and cell death pathways. J Am Chem Soc. 2013; 135:14060-14063.

60. Matsuoka S, Rotman G, Ogawa A, Shiloh Y, Tamai K, Elledge SJ. Ataxia telangiectasia-mutated phosphorylates Chk2 in vivo and in vitro. Proc Natl Acad Sci USA. 2000; 97:10389-10394.

61. Shieh SY, Ikeda M, Taya Y, Prives C. DNA damage-induced phosphorylation of p53 alleviates inhibition by MDM2. Cell. 1997; 91:325-334.

62. Ahn JY, Schwarz JK, Piwnica-Worms H, Canman CE. Threonine 68 phosphorylation by ataxia telangiectasia mutated is required for efficient activation of Chk2 in response to ionizing radiation. Cancer Res. 2000; 60:5934-5936.

63. Sinha R, Ei-Bayoumy K. Apoptosis is a critical cellular event in cancer chemoprevention and chemotherapy by selenium compounds. Curr. Cancer Drug Targets. 2004; 4:13-28.
64. Bloom J, Cross FR. Multiple levels of cyclin specificity in cell-cycle control. Nat Rev Mol Cell Biol. 2007; 8:149-160.

65. Wang C, Youle RJ. The role of mitochondria in apoptosis. Annu Rev Genet. 2009; 43:95-118.

66. Torchilin V. Tumor delivery of macromolecular drugs based on the EPR effect. Adv Drug Deliv Rev. 2011; 63:131-135.

67. Fang J, Nakamura H, Maeda $H$. The EPR effect: Unique features of tumor blood vessels for drug delivery, factors involved, and limitations and augmentation of the effect. Adv Drug Deliv Rev. 2011; 63:136-151.

68. Maeda H, Nakamura H, Fang J. The EPR effect for macromolecular drug delivery to solid tumors: Improvement of tumor uptake, lowering of systemic toxicity, and distinct tumor imaging in vivo. Adv Drug Deliv Rev. 2013; 65:71-79.

69. Iyer AK, Khaled G, Fang J, Maeda H. Exploiting the enhanced permeability and retention effect for tumor targeting. Drug Discov Today. 2006; 11:812-818.

70. Maeda H, Sawa T, Konno T. Mechanism of tumor-targeted delivery of macromolecular drugs, including the EPR effect in solid tumor and clinical overview of the prototype polymeric drug SMANCS. J Controlled Release. 2001; 74:47-61.

71. Tiruppathi C, Song W, Bergenfeldt M, Sass P, Malik AB. Gp60 activationmediates albumin transcytosis in endothelial cells by tyro sine kinase-dependent pathway. J Biol Chem. 1997; 272:25968-25975.

72. Sage H, Johnson C, Bornstein P. Characterization of a novel serum albumin-binding glycoprotein secreted by endothelial cells in culture. J Biol Chem. 1984; 259:3993-4007.

73. Kratz F. A clinical update of using albumin as a drug vehicle-A commentary. J Controlled Release. 2014; 190:331-336.

74. Wosikowski K, Biedermann E, Rattel B, Breiter N, Jank P, Löser R, Jansen G, Peters GJ. In vitro and in vivo antitumor activity of methotrexate conjugated to human serum albumin in human cancer cells. Clin Cancer Res. 2003; 9:1917-1926.

75. Sheldrick GM. SHELXTL V5.1: Software Reference Manual, Bruker AXS, Inc., Madison, WI, USA, 1997.

76. Curry S, Mandelkow H, Brick P, Franks N. Crystal structure of human serum albumin complexed with fatty acid reveals an asymmetric distribution of binding sites. Nat Struct Biol. 1998; 5:827-835.

77. DeLano WL. The PyMol Molecular Graphics System, DeLano Scientific: San Carlos: CA, 2004.

78. Du C, Deng D, Shan L, Wan S, Cao J, Tian J, Achilefu $\mathrm{S}, \mathrm{Gu} \mathrm{Y}$. A pH-sensitive doxorubicin prodrug based on folate-conjugated BSA for tumor-targeted drug delivery. Biomaterials. 2013; 34:3087-3097. 